NBER WORKING PAPER SERIES

\title{
WHY ARE SOME PEOPLE (AND COUNTRIES) MORE PROTECTIONIST THAN OTHERS?
}

\author{
Anna Maria Mayda \\ Dani Rodrik \\ Working Paper 8461 \\ http://www.nber.org/papers/w8461
NATIONAL BUREAU OF ECONOMIC RESEARCH
1050 Massachusetts Avenue
Cambridge, MA 02138
September 2001

We thank Pippa Norris for acquainting us with the ISSP data set, and the Ford Foundation for financial support. Seminar participants at Harvard, Stanford, and the NBER have provided very useful comments. We also thank Gary Chamberlain and Jack Porter for valuable econometric advice, and Zoe McLaren for editorial assistance. The views expressed herein are those of the authors and not necessarily those of the National Bureau of Economic Research.

(C) 2001 by Anna Maria Mayda and Dani Rodrik. All rights reserved. Short sections of text, not to exceed two paragraphs, may be quoted without explicit permission provided that full credit, including $\odot$ notice, is given to the source. 
Why Are Some People (and Countries) More Protectionist Than Others?

Anna Maria Mayda and Dani Rodrik

NBER Working Paper No. 8461

September 2001

JEL No. F10

\begin{abstract}
$\underline{\text { ABSTRACT }}$
We analyze a rich cross-country data set that contains information on attitudes toward trade as well as a broad range of socio-demographic and other indicators. We find that pro-trade preferences are significantly and robustly correlated with an individual's level of human capital, in the manner predicted by the factor endowments model. Preferences over trade are also correlated with the trade exposure of the sector in which an individual is employed: individuals in non-traded sectors tend to be the most protrade, while individuals in sectors with a revealed comparative disadvantage are the most protectionist. Third, an individual's relative economic status, measured in terms of either relative income within each country or self-expressed social status, has a very strong positive association with pro-trade attitudes. Finally, non-economic determinants, in the form of values, identities, and attachments, play an important role in explaining the variation in preferences over trade. High degrees of neighborhood attachment and nationalism/patriotism are associated with protectionist tendencies, while cosmopolitanism is correlated with pro-trade attitudes. Our framework does a reasonable job of explaining differences across individuals and a fairly good job of explaining differences across countries.
\end{abstract}

\author{
Anna Maria Mayda \\ Department of Economics \\ Harvard University \\ Cambridge, MA 02138 \\ mayda@fas.harvard.edu
}

\author{
Dani Rodrik \\ Kennedy School of Government \\ Harvard University \\ Cambridge, MA 02138 \\ and NBER \\ (617) 495-9454 \\ dani_rodrik@harvard.edu
}




\title{
Why ARE SOME PEOPLE (AND COUNTRIES) MORE PROTECTIONIST THAN OTHERS?
}

\author{
Anna Maria Mayda and Dani Rodrik
}

\section{$\underline{\text { I. Introduction }}$}

Economists disagree intensely on many public policy issues. What is the best way to deal with poverty? What is the appropriate role of the government in providing health insurance? Should Microsoft be broken up? Does counter-cyclical macroeconomic policy make sense? Should social security be privatized? Should we tax international capital flows? Is the minimum wage desirable? In these and many other areas, economists are engaged in lively controversies that reflect broader public debates on social problems.

International trade poses an interesting contrast. Here the debates remain largely technical, even among policy-oriented economists: which theory is more appropriate in explaining the patterns of trade? How much, if at all, has trade contributed to the rise in the skill premium in the U.S.? Why are "border effects" so large? On the important policy questions that excite the public, there is virtually no difference of views. The consensus among mainstream economists on the desirability of free trade remains almost universal.

It is striking how little this consensus resonates with public opinion. When asked about their views on trade, typically sixty percent or more of respondents in opinion polls express antitrade views. While there are some interesting differences across countries, which we shall document and analyze later, a majority of respondents tend to be in favor of restricting trade regardless of national context.

Our purpose in this paper is to shed light on this phenomenon, by undertaking a systematic analysis of individual preferences on trade and their underlying determinants. We make use of an interesting cross-country data set put together by the International Social Survey 
Programme (ISSP), which allows us to perform a comparative analysis covering more than 20,000 individuals in 23 countries. As our title indicates, we are interested in uncovering the determinants of individual preferences on trade. We use as our dependent variable a question in the ISSP data set that asks whether the respondent favors restricting trade. The data set also contains a wealth of information on demographics, socio-economic status, and values, which we use to test a number of hypotheses about the formation of preferences.

The standard workhorse models of international trade have well-defined implications for the distributive consequences of trade and hence for individual preferences (see Rodrik 1995 for a review of the literature). Under the factor-endowments model, which assumes costless intersectoral mobility of productive factors, trade benefits individuals who own the factors with which the economy is relatively well endowed, and hurts the others. This is the well-known Stolper-Samuelson theorem. Under the specific-factors model, trade benefits individuals who are employed in the export-oriented sectors and hurts those who are employed in the importcompeting sectors. To the extent that individuals are motivated by material self-interest, these models provide important hints about an individual's likely attitude to trade depending on his/her factor type or sector of employment.

Our first set of results relates directly to these economic models. Most strikingly, and somewhat contrary to our own priors, we find strong support for the factor-endowments view of the world. Individuals with higher levels of human capital (proxied by educational attainment) oppose trade restrictions, but only in countries that are well endowed with human capital. Higher levels of education are associated with pro-trade views in advanced countries such as Germany and the United States, but with anti-trade views in the Philippines (the poorest country in our sample). Most of the other countries are intermediate between these two extremes. That 
individual trade preferences interact with country characteristics in exactly the manner predicted by the factor-endowments model may be considered surprising, but it is a robust result and perhaps our strongest single finding.

We find some support for the sector-specific factors model as well. In particular, individuals employed in import-competing industries are more likely to be in favor of trade restrictions (compared to individuals in non-traded sectors). However, individuals in exportoriented sectors are not significantly less predisposed to trade restrictions (compared again to individuals in non-traded sectors). This finding can be rationalized within the sector specific model by appealing to the presence of intra-industry (two-way) trade: individuals in exportoriented sectors still feel the pressure of imports and thus their attitudes to trade are intermediate: they do not favor trade as much as individuals in non-traded sectors, but neither are they as protectionist as individuals in import-competing sectors.

The fact that the factor-endowments and sector-specific models both find support in the data suggests that individuals may differ in their perceptions of inter-sectoral mobility. Some view themselves as mobile over the relevant time horizon (and express preferences in line with the factor-endowments model), while others view themselves as immobile (and express preferences in line with the sector-specific factors model). We find evidence that is loosely consistent with this reading when we use the (imperfect) measure of mobility that is contained in our dataset.

While the implications of conventional economic models are borne out by the data, these models go only part of the way in explaining the formation of preferences. We find that social status, relative incomes, values, and attachments play, if anything, a more important role. In particular, one of our key findings is that attitudes toward trade are closely linked to an 
individual's relative standing on the domestic income scale. Individuals with incomes greater than the national average tend to favor trade while those with below-average incomes favor protection. Interestingly, it is income relative to the national average, rather than the absolute level of income, that is correlated with trade preferences. Subjective evaluations of social status bear a similar relationship to trade preferences: individuals who consider themselves part of the upper classes tend to be more favorable to trade than those who consider themselves to be from the lower classes. These findings are suggestive of a link between income distribution and trade preferences that is independent of factor ownership and sector of employment.

Our final set of results relates to self-expressed values, identities, and attachments. Protectionist attitudes go together with a well-defined set of normative attributes. Individuals who favor trade restrictions tend to have high attachments to their neighborhood and community, have a high degree of national pride, and believe that national interest should be paramount in making trade-offs. At the same time, individuals who have confidence in their country's democracy and economic achievements are less likely to favor trade protection. Therefore, the picture that emerges is this: communitarian-patriotic values tend to foster protectionist attitudes, but this tendency is moderated when the broader institutions of society are perceived to be working well.

The bottom line is that both economic and non-economic considerations are important in determining attitudes towards trade. Once we take the myriad factors discussed above into account, we are reasonably successful in explaining the variation in trade preferences in our sample. Our preferred "combined" model accounts for about a fifth of the sample variance. Moreover, we are also reasonably successful in explaining the differences in mean preferences 
across countries. Our preferred model does a good job of explaining why respondents in Poland, for example, are more protectionist on average than those in Germany.

The empirical literature on the political economy of trade policy is not small, but it has focused largely on testing the implications of the factor-endowments and sector-specific factors models. Thus, studies that have found support for the factor-endowments model include Rogowski (1987, 1989), Midford (1993), Beaulieu (1996) Balistreri (1997), and Scheve and Slaughter $(1998,2001)$. Studies that have found support for the sector-specific model include Magee (1978) and Irwin $(1994,1996)$. Some have found support for both views of the world (Baldwin and Magee 1998 and Beaulieu and Magee 2001). With the exception of Balistreri (1997) and Scheve and Slaughter (1998), none of these studies analyze individual preferences directly. Instead they infer preferences from aggregated information on voting, campaigncontributions, or policy outcomes. ${ }^{1}$ Also, no study to date has analyzed these issues in a crossnational framework.

Since we began our work with the ISSP data set we have become aware of two other related, but independent papers: O'Rourke and Sinnott (2001) and Beaulieu, Benarroch, and Gaisford (2001). Both of these papers use the ISSP survey to explore the determinants of trade preferences. The O'Rourke and Sinnott paper is closest to ours, and many of its conclusions parallel our own findings. We find this reassuring since some of the methodological choices we have made quite naturally differ. ${ }^{2}$ Beaulieu et al. (2001) focus more narrowly on testing the Stolper-Samuelson theorem. Their conclusions on Stolper-Samuelson are at variance with ours:

\footnotetext{
${ }^{1}$ For example, Irwin $(1994,1996)$ looks at the outcomes of the 1906 and 1923 British general elections and interprets them as proxies for voters' preferences on new trade barriers.

${ }^{2}$ Some of the key differences are as follows: O'Rourke and Sinnott (2001) measure human capital differently, use ordered probit (we use ordered logit), do not test the sector-specific model, and do not focus on relative-income or status.
} 
we (along with O'Rourke and Sinnott 2001) find strong support, while they do not, for reasons we shall discuss briefly later on.

The plan of the paper is as follows. In the next section, we briefly describe the data and the methods we have used. Next, we present a series of empirical models highlighting different types of determinants of trade preferences. In the penultimate section, we put all our results together and comment on the overall fit of our explanatory framework. A final section concludes.

\section{$\underline{\text { II. Description of the data and empirical approach }}$}

The International Social Survey Programme (ISSP) collects cross-national data by combining national surveys on topics that are important for social science research (http://www.issp.org/). In this paper we use data from the 1995 ISSP National Identity module (ISSP-NI). The data set covers information at the individual level on some 28,456 respondents from 23 countries, including the United States, Canada, Japan, many Western and Eastern European countries, and one developing country (the Philippines). ${ }^{3}$ For each individual, the data set contains responses on a variety of topics, ranging from opinions on trade and immigration policy to feelings of patriotism and regional attachment. In addition, the ISSP-NI data set contains information on several economic and demographic variables. Thus the survey allows us to identify both stated trade policy preferences and individual characteristics that explain attitudes towards trade in standard economic models. Since not all questions are covered in individual country surveys, our regressions will typically not include all 23 countries.

\footnotetext{
${ }^{3}$ The full list of countries covered in the data set comprises West Germany, East Germany, Great Britain, United States, Austria, Hungary, Italy, Ireland, Netherlands, Norway, Sweden, Czech Republic, Slovenia, Poland, Bulgaria, Russia, New Zealand, Canada, Philippines, Japan, Spain, Latvia, and Slovak Republic.
} 
In order to measure individual trade policy preferences, we focus on survey answers to the following question:

Now we would like to ask a few questions about relations between (respondent's country) and other countries. How much do you agree or disagree with the following statements: (Respondent's country) should limit the import of foreign products in order to protect its national economy.

1. Agree strongly

2. Agree

3. Neither agree nor disagree

4. Disagree

5. Disagree strongly

8. Can't choose, don't know

9. NA, refused

After deleting the "Can't choose, don't know" and "NA, refused" responses, we transformed survey questions into the dependent variable TRADE_OP (with answers ranging from 1=agree strongly to 5=disagree strongly). Higher values of TRADE_OP therefore correspond to preferences that are more pro-trade and less protectionist. TRADE_OP is our preferred dependent variable, and we use it in most of our empirical exercises.

We also created two binary variables, which we label TRADEPRO and TRADECON. TRADEPRO is set equal to unity for individuals opposing trade protection (i.e. for those replying "disagree" or "disagree strongly" to the question), and to zero for the rest. TRADECON is set equal to unity for individuals favoring trade protection (i.e. for those replying "agree" or "agree strongly" to the question), and to zero for others. We ran probit regressions with TRADEPRO and TRADECON. Since the results were virtually indistinguishable from those with the ordered logits using TRADE_OP, we shall not report them here.

Table 1 presents summary statistics for TRADE_OP, TRADEPRO and TRADECON, by country. Several results stand out. First, as in previous analyses, protectionist sentiment runs 
high on average. Taking the 23 countries as a whole, more than half of the respondents agree with the proposition that trade should be restricted (average TRADECON $=0.58$ ), while fewer than a quarter disagree (average TRADEPRO $=0.23$ ). Second, there is quite a large variation in trade preferences across countries. Netherlands emerges as the country that is the most pro-trade $($ TRADEPRO $=0.40)$ while Bulgaria is the most protectionist $($ TRADEPRO $=0.09)$, regardless of the indicator used. Third, as the last comment indicates, the rankings of the countries are not very sensitive to the measure of trade preferences. Generally, the continental European countries tend to be the most free trade oriented, while the former socialist economies of Europe are the most protectionist. The United States is intermediate between these two groups.

Are these findings truly reflective of underlying attitudes towards trade? It is well known that survey responses tend to be highly sensitive to framing--the phrasing of the question and the context and order in which it is asked. In this particular case, there is especially cause to worry because the question in ISSP-NI refers to possible benefits of restricting imports ("protecting national economy") without mentioning any drawbacks. One would suspect that this imparts a strong protectionist bias to the responses. There are two countervailing considerations. First, there is ample evidence from the U.S., which suggests that the precise phrasing of the question on imports does not greatly affect the average responses provided (see the review in Scheve and Slaughter 2001). Second, in our empirical work, we will be interested in identifying the determinants of the differences in attitudes across individuals. Even though the responses on trade may be biased in one direction, our results will not be affected unless the magnitude of the bias is also correlated with our explanatory variables.

We might also wonder whether protectionist sentiment, as captured by surveys of this kind, has any relationship to actual trade policies. There are of course good reasons to believe 
that in any political system there would be considerable slippage between individual preferences on any specific issue and policy outcomes. The "supply" side of policy can be as important as the "demand" side. Moreover, the institutional structures of government and of political representation mediate between individual voters and policy makers. This is shown schematically in Figure 1 (taken from Rodrik 1995). Nonetheless, it is interesting to know whether trade preferences broadly correlate with trade policies in our sample.

Figure 2 shows that the answer is broadly yes. The correlation between average values of TRADE_OP and average level of trade duties across countries is negative and statistically significant (robust t-statistic $=-2.13$, significant at $5 \%$ level). ${ }^{4}$ The point estimate suggests that a one-point increase in TRADE_OP on our 5-point scale is accompanied with a 3.6 percentage point reduction in average duties. At the same time, it is clear from the figure that the relationship is quite a loose one: TRADE_OP accounts for no more than 8 percent of the crosscountry variation in average tariffs.

In the following, we shall use TRADE_OP as our dependent variable and estimate a series of ordered logit models. Ordered logit is our preferred specification because it preserves the maximum amount of the information in the dependent variable without imposing linearity on the underlying relationship between the explanatory variables and the 5-point scale on which TRADE_OP is calibrated. ${ }^{5}$ Appendix I provides more information on the technical aspects of the ordered logit. We have checked the robustness of our results to alternative specifications,

\footnotetext{
${ }^{4}$ Trade duties refer to combined import and export duties (tm and tx, respectively) over the 1992-98 period, calculated as $[(1+\mathrm{tm}) *(1+\mathrm{tx})]-1$. The source for duties is the World Development Indicators CD-Rom of the World Bank. Two countries, Slovenia and Slovak Republic, are not included in Figure 1 because the World Bank does not provide data on duties for them.

${ }^{5}$ An alternative would have been to estimate ordered probit models, as is done in O'Rourke and Sinnott (2001). The ordered logit assumes that the error term in the underlying latent relationship is distributed logistically, while the ordered probit assumes it is distributed normally.
} 
running probit regressions with TRADEPRO and TRADECON as well as OLS regressions with TRADE_OP. We find very few substantive differences so we shall not present the results from these different specifications. In most of our specifications, we will include a full set of country dummies to minimize the likelihood of picking up spurious correlations between regressors and TRADE_OP. With few exceptions, the inclusion of country fixed effects did not affect the results either.

One shortcoming of the ordered logit is that the coefficient estimates are hard to interpret. As explained in the appendix, even the sign of an estimated coefficient has to be interpreted cautiously: it provides an unambiguous signal with respect to the marginal probabilities of only the top and bottom categories (or groups of categories) on the 5-point scale of our dependent variable. Rather than cluttering the tables with estimated coefficients, therefore, we will report two measures for each regressor that indicate the estimated increase in the probability of each of the highest two categories ("disagree" and "disagree strongly" with trade restrictions) given a marginal increase in the value of the relevant regressor, holding all other regressors at their mean value. We will often refer to the sum of the two marginal effects presented in the tables, since this sum represents the estimated impact that a regressor has on the probability that an "average" individual will be pro-trade (i.e., "disagree" or "disagree strongly" with trade restrictions).

III. A first pass: the naive demographic model

As a first pass through the data, we ignore economic theory and present some estimates that relate trade attitudes to a laundry list of standard demographic characteristics. We use information from other ISSP-NI questions regarding age, gender, citizenship, years of education, 
area of residence (rural vs. urban), subjective social class, political party affiliation, trade union membership and real income. ${ }^{6}$ The results are shown in Table 2.

We find strong gender and age effects on trade preferences, which survive virtually all specifications we have tried. Column (1) in Table 2 shows that being a male increases the probability of replying "disagree" and "disagree strongly" with trade restrictions by respectively 4.8 and 2.6 percentage points (both significant at the $1 \%$ level). In other words males are on average 7.4 percentage points more likely to be pro-trade, which is quite a striking difference given that only 23 percent of the sample overall is pro-trade. This gender-based difference in trade attitudes provides us with an early glimpse into the important role played by values in shaping preferences. ${ }^{7}$ Older individuals are significantly more protectionist. Citizenship in the country and rural residence are both negatively associated with pro-trade sentiments.

Table 2 also shows that education and income are positively associated with pro-trade attitudes. However, we shall significantly qualify both conclusions in the analysis that follows. Individuals who identify themselves as being from the upper classes are more likely to be protrade, while political party affiliation has no significant relationship with trade preferences. Trade union membership is associated with protectionist attitudes. Regressions without fixed effects for countries (not shown) yield very similar results, except in the case of trade union membership. When country dummies are excluded, trade union membership does not have a statistically significant negative relationship with TRADE_OP. We interpret this to be the result

\footnotetext{
${ }^{6}$ The log of real income is calculated using data in local currency on individual income from the ISSP-NI data set and purchasing power parity conversion factors from the WDI (World Bank). Education refers to years of education, with a maximum top-coding (introduced by us) of 20.

${ }^{7}$ An alternative hypothesis would be that gender differences arise from the significantly lower levels of labormarket participation of women. Leaving aside the question of why this should produce the bias in question, this alternative hypothesis is not borne out by the data. The strong gender difference persists even after we control for whether an individual is in the labor market or not.
} 
of a spurious positive correlation between high levels of union membership and relatively high incidence of pro-trade preferences that arises from the presence of a number of continental European countries, which on average exhibit both characteristics. This confounding effect is eliminated in the presence of fixed effects.

When we modify the naï ve demographics specification below, we shall drop some of these variables (area of residence, subjective social class, political party affiliation and trade union membership) because we would be losing too many observations to missing values otherwise. We shall keep age, gender, citizenship and education as controls in all specifications.

\section{Economic determinants of individual preferences: The factor endowments model}

Moving towards free trade, a country that is well endowed with skilled labor will experience an increase in the relative price of skill-intensive goods and correspondingly specialize in the production of those goods. According to the Stolper-Samuelson theorem, skilled workers in all sectors of the economy will gain and unskilled workers will lose. A key assumption of the factor endowments model--of which the Stolper-Samuelson theorem is an implication--is that factors of production can move costlessly across economic sectors. This is an extreme assumption. However, as long as individuals perceive themselves to be intersectorally mobile over the relevant time horizon, their preferences over trade policy will still be informed by the underlying logic of the Stolper-Samuelson theorem. In this section, we test this idea.

We use as our theoretical backdrop a world in which skilled and unskilled labor are the only relevant factors of production. We do not have information on capital ownership, so we shunt it aside by assuming that it plays an insignificant role in shaping comparative advantage, 
perhaps because it is internationally mobile. Our measure of skill is years of education (educyrs), which we have already used above.

According to the factor endowments model, an individual's trade policy preferences will depend both on his skill level and on his country's relative factor endowment. A skilled individual will be pro-trade in an economy that is well endowed with skilled labor, but anti-trade in an economy that is well endowed with low-skill labor. So we need information also on an economy's relative abundance in skilled labor. We shall use three different measures as proxies for relative factor endowments. The first of these is per-capita GDP. It is reasonable to suppose that countries with higher GDP per capita are also better endowed with skilled labor. The second and third measures are based on the actual average years of education in our sample for each country. $^{8}$

Before we present regression results, it is instructive to examine whether the estimated effect of educyrs varies systematically across countries in the manner predicted by the StolperSamuelson theorem. So we first ran a series of probit regressions on individual countries, with TRADEPRO as the dependent variable. In each case, we regressed TRADEPRO on educyrs (along with age and male). In Figure 3, we plot the estimated marginal effects we obtained on educyrs alongside each country's per-capita GDP. The result is striking: there is a very strong and tight relationship between a country's per-capita GDP and the magnitude of the corresponding estimated marginal effect of educyrs (the coefficient of per capita GDP is $1.53 \mathrm{e}-$ 06 , robust t-statistic $=4.97$, significant at $1 \%$ level). The richer a country, the more positive is the

\footnotetext{
${ }^{8}$ We could have also used the Barro-Lee (1996 and 2000) data sets, but these suffer from some clear defects where the countries in our sample are concerned. For example, when we construct a measure of relative human capital endowment (high-skilled vs low-skilled labor) by considering no schooling and primary schooling attainment in the low-skilled labor measure and secondary schooling and higher schooling attainment in the high-skilled labor measure, we obtain that West Germany and Spain rank lower than the Philippines in 1990.
} 
impact of a marginal increase of education on the probability of pro-trade attitudes. The Philippines lies at the low end of the spectrum, and is without question the country with the lowest skill endowment in our sample. The marginal effect of educyrs we obtained for the Philippines is not only the smallest among all countries, it is actually negative (and statistically significant at the $1 \%$ level). Greater education is associated with more protectionist views in the Philippines--the only such case in our sample. These findings are quite in line with the StolperSamuelson theorem.

In Table 3 we show pooled regressions with country dummy variables where we take into account the cross-country heterogeneity with respect to educyrs. In the first set of regressions, we interact educyrs with $\log$ per-capita GDP, educyrs $* g d p$, and enter the two variables separately. The previous exercise on individual countries suggests that the impact of educyrs should depend on the level of per-capita GDP; that is, we should get a negative coefficient on educyrs but a positive coefficient on the interaction term $e d u c y r{ }^{*} g d p$. This is exactly what we get. ${ }^{9}$ Both terms are highly significant. Column (2) confirms that the result is robust to controlling for an individual's real income. Columns (3) and (4) confirm that the pattern continues to hold when we drop the Philippines and the other lower-income countries from the sample. ${ }^{10}$ This is important evidence, suggesting that the non-linearity in educyrs is present for the entire range of countries; it is not an artifact driven by either the Philippines or a small number of low-income countries. Column (5) introduces an additional interaction term between

\footnotetext{
${ }^{9}$ O'Rourke and Sinnott (2001) have independently replicated this result, even though their measure of skill is different from ours. These authors use an occupational measure, in contrast to our educational measure.

${ }^{10}$ The countries dropped are Poland, Bulgaria, Russia, Latvia and the Philippines.
} 
individual income and per-capita GDP, income* ${ }^{*} d p$, to confirm that what we are capturing is a non-linearity in the impact of education, and not with respect to income/earnings.

We next use an alternative measure of national factor endowments by taking the sample average years of education in each country to construct an interaction variable, educyrs*educ, which is the product of the latter measure with educyrs. When we enter both variables in regression (6), we find results that are similar to those above. The estimated impact of education on pro-trade attitudes is nonlinear--negative in skill-scarce countries and positive in skillabundant countries. The estimates are statistically significant as before.

Finally, we construct a third measure of country-level factor-endowments. We again compute the average years of education of all individuals in each country $\left(e_{k}\right)$, then we calculate a population-weighted average of national skilled-labor endowments of the countries in the sample $(\bar{e})$ and, finally, we compare each country's value to this global average. We label $s k$ the measure of each country's relative abundance of skilled labor and unsk the measure of each country's relative scarcity of skilled labor. The two variables are defined as follows:

$$
\begin{gathered}
s k=\max \left(\mathrm{e}_{\mathrm{k}}-\overline{\mathrm{e}}, 0\right) \\
u n s k=\min \left(\mathrm{e}_{\mathrm{k}}-\overline{\mathrm{e}}, 0\right)
\end{gathered}
$$

Next, we construct two interaction variables, educyrs*sk and educyrs*unsk, by multiplying both sk and unsk with educyrs. According to the factor endowments model, both coefficients on the interaction variables should be positive. Our results, shown in column (7), are only partially consistent with this prediction, with the coefficient on educyrs ${ }^{*} s k$ being negative and the coefficient on $e d u c y r s^{*} u n s k$ being positive. This result is most likely due to the way in which the cut-off point $\bar{e}$ has been constructed, i.e. averaging national skilled-labor endowments only over the countries in the ISSP-NI sample. 
Overall, these findings are strikingly supportive of the implications of the factor endowments model and of the Stolper-Samuelson theorem. Education is very strongly correlated with support for free trade in countries that are well endowed with human capital. It is either weakly or negatively correlated with support for free trade in countries that are poorly endowed with human capital. $^{11}$

$\underline{\text { V. Economic determinants of individual preferences: The sector-specific factors model }}$

If individuals are, or perceive themselves to be, immobile across industries, their attitudes towards trade should be determined by their sector of employment, rather than their factor type. Individuals in sectors where the home economy has a comparative advantage should be protrade; individuals in comparative disadvantage sectors should be protectionist; and individuals in non-traded sectors on balance indifferent or pro-trade. This is the central insight of the sectorspecific factors model.

In taking this insight to our data, we face an immediate problem. The ISSP-NI survey contains no direct question about sector of employment. But it does provide fairly detailed information on occupation (based on the International Standard Classification of Occupations [ISCO] or national classifications). We do our best to infer sector of employment from this data on occupation. Since our goal is to establish a correspondence between these sectors and

\footnotetext{
${ }^{11}$ As we mentioned in the introduction, Beaulieu et al. (2001) interpret these data differently, as rejecting the Stolper-Samuelson theore $m$. They note that skilled workers tend to be more pro-trade in virtually all the countries in the ISSP sample. However, this overlooks the fact that the countries covered by the ISSP are at the high end of the world income/skill distribution. Beaulieu et al. (2001) do note that the relationship between education and trade preferences is reversed (Philippines) or weak (Bulgaria, Russia, Latvia, and Slovakia) in some of the individual countries. But they do not find this to be evidence in favor of Stolper-Samuelson, largely because they rely on tertiary enrollment per capita (a very problematic statistic, in our view) to rank countries according to their human capital endowment. By this measure, the relative human capital endowment of the Philippines is the same as Sweden's, Austria's or Japan's, while that of West Germany lies below Spain's, Bulgaria's, and the Philippines' (Table 3 in Beaulieu et al.).
} 
international trade data, we recode the occupation variables according to the industry classification used in the World Trade Analyzer (WTA) data set. In particular, we end up reorganizing the data on the basis of a breakdown into 34 manufacturing industries as defined by the U.S. Bureau of Economic Analysis (BEA). Since the occupation codes used in the ISSP-NI data set are not always detailed enough to be matched with any single BEA code, we create in addition new codes as combinations of the original 35 codes. This results in a total of 54 (partly overlapping) sectors. We treat non-manufacturing industries as non-tradables. The details of our procedures and the sectoral breakdown we use are discussed in Appendix II. In some cases, the mapping is straightforward, as many occupational codes (e.g., "dairy and livestock producers," "chemical-processing-plant operators," or "aircraft engine mechanics and fitters") are directly indicative of sectors. In other cases, it is impossible to assign an individual to a specific sector, and this results in either a less precise recoding or in missing values.

We determine a sector's revealed comparative advantage/disadvantage by looking at the sign of adjusted net exports in that sector (averaged over the years 1990-95). The adjustment is meant to "correct" for the existence of overall trade imbalances. Hence, we define an adjustment factor, $\lambda$, as follows:

$$
\lambda=\frac{\sum_{\mathrm{i}}\left(\mathrm{M}_{\mathrm{i}}-\mathrm{X}_{\mathrm{i}}\right)}{\sum_{\mathrm{i}} \mathrm{M}_{\mathrm{i}}}
$$

The indicator $\lambda$ is positive for countries that have a trade deficit and negative for countries with a trade surplus. In particular, $\lambda$ tells us by what fraction imports in each sector would have to be reduced in order to balance the trade account. Our measure of adjusted net exports in each sector is the difference between $X_{i}$ and $(1-\lambda) M_{i}$. We then define the two sector-specific variables, 
$\mathrm{CA}_{\mathrm{ik}}$ (comparative advantage sector) and $\mathrm{CD}_{\mathrm{ik}}$ (comparative disadvantage sector) for each sector $\mathrm{i}$ in country $\mathrm{k}$ as follows:

$$
\begin{aligned}
& \mathrm{CA}_{\mathrm{ik}}=\left\{\begin{array}{l}
1, \text { if } \mathrm{M}_{\mathrm{ik}}-\mathrm{X}_{\mathrm{ik}}-\lambda \mathrm{M}_{\mathrm{ik}}<0, \text { for sector } \mathrm{ik}_{\mathrm{ik}}=1, \ldots, 54 \\
0, \text { if } \mathrm{M}_{\mathrm{ik}}-\mathrm{X}_{\mathrm{ik}}-\lambda \mathrm{M}_{\mathrm{ik}}>0 \text { for sec tor } \mathrm{ik}_{\mathrm{ik}}=1, \ldots, 54 \text { or if nontradabl e sector }
\end{array}\right. \\
& \mathrm{CD}_{\mathrm{ik}}= \begin{cases}1, \text { if } & \mathrm{M}_{\mathrm{ik}}-\mathrm{X}_{\mathrm{ik}}-\lambda \mathrm{M}_{\mathrm{ik}}>0, \text { for sector } \\
0, \text { if } & \mathrm{M}_{\mathrm{ik}}-\mathrm{X}_{\mathrm{ik}}-\lambda \mathrm{M}_{\mathrm{ik}}<0, \text { for sector } \\
\mathrm{ik} & =1, \ldots, 54 \text { or if nontradable sector }\end{cases}
\end{aligned}
$$

A sector is defined as a comparative advantage sector if its adjusted net imports are less than zero and as a comparative disadvantage sector if its adjusted net imports are greater than zero. Each individual is therefore assigned to one of three types of sectors: (a) a comparative advantage sector; (b) a comparative disadvantage sector; or (c) a non-tradable sector. ${ }^{12}$

The first regression in Table 4 shows the results. An individual in a comparative disadvantage sector is significantly less likely to be pro-trade compared to an individual in a nontraded sector (with a difference of 4.3 percent). This is highly supportive of the sector-specific factors model. Perhaps surprisingly, an individual in a comparative advantage sector is also less likely to be pro-trade than an individual in a non-traded sector, although the differences are not statistically significant in this case.

The latter result can be rationalized by considering the original survey question, which is meant to elicit preferences related to restrictions on imports only. In the presence of two-way (intra-industry) trade, it can be rational for individuals to prefer import restrictions in their sectors even when those sectors are large exporters on balance. Additionally, our sectoral classification and aggregation procedures may have resulted in the lumping together of $\mathrm{CA}$ and

\footnotetext{
12 This is true unless (1) the individual has not reported his occupation; or (2) his occupation cannot be matched to any industry code nor to the non-tradable sector; or (3) there are no data on imports and exports for his sector of employment. In all these cases the individual is assigned a missing value.
} 
CD sectors. Whatever the reason, the bottom line that emerges from this regression is that the main cleavage in preference formation over trade lies not between the two tradable sectors but between import-competing and non-tradables sectors. ${ }^{13}$

An alternative specification, which takes into account the presence of two-way trade, is shown in column (2). Now we enter separately the actual volumes of exports and imports (normalized by GDP) of the sector in which an individual is employed. The logic of the sectorspecific model (augmented by the possibility of two-way trade) is that the estimated coefficient on imports should be negative. The estimated coefficient on exports should be positive to the extent that individuals fear retaliation from abroad or see through the Lerner symmetry theorem. We do indeed find a negative (and borderline insignificant) effect on the imports term. The estimated coefficient on exports, however, remains negative and insignificant.

In columns (3) and (4), we carry out a joint test of the factor endowments and sector specific models. There are essentially no important differences from the individual tests, and both models survive. How do we explain this? A plausible interpretation is that a certain fraction of individuals in our sample view themselves as inter-sectorally mobile over the time horizon that is relevant to them, and a certain fraction think of themselves as stuck in their present line of employment. The first group's trade preferences would be in accordance with the factor endowments model, while the second group's preferences would be in accordance with the sector specific model.

The ISSP data set contains some questions on mobility. In particular, individuals are asked: "If you could improve your work or living conditions, how willing or unwilling would you be to move to another town or city?" Answers to the questions range from "very

\footnotetext{
${ }^{13}$ When we drop individuals employed in non-tradable sectors from the regression, we find no statistically significant difference between the attitudes of individuals in the CD and CA sectors.
} 
unwilling"(1) to "very willing" (5). The question relates to geographical mobility rather than inter-sectoral mobility, but may still be indicative of the latter. This gives us an opportunity to check whether willingness to move relates to trade attitudes in the manner consistent with our interpretation.

We interact willingness to move with the CA and CD indicators used previously, and enter the interaction terms along with willingness to move. The results are shown in column (5). First, individuals with greater willingness to move are more likely to be pro-trade, as expected. Second, the sign on the comparative advantage term (CA sector) now becomes positive, in line with the original expectations from the sector-specific factors model (but the marginal effect is insignificant). Third, individuals in CA sectors are less pro-trade if their willingness to move is high (and this interactive effect borders on statistically significance). Fourth, individuals in CD sectors express more pro-trade sentiments when their stated willingness to move is high, although the interaction term is not close to significance. Hence the signs on the estimated coefficients are all consistent with our interpretation, but the insignificance of most of the estimates prevents us from reading too much support into this.

\section{$\underline{\text { VI. Economic determinants of individual preferences: Relative-income/status model }}$}

In some of the specifications we discussed previously, we saw that an individual's real income is associated positively with pro-trade attitudes, even after controlling for education and other socio-demographic attributes. In this section, we refine this finding and demonstrate that it is relative income within a country rather than its absolute level that matters.

Our measure of relative income is earnrel, which is the ratio of an individual's income to the sample average income in the relevant country. Table 5 shows the results. In column (1), we 
see that an individual whose income is double the country's average (earnrel $=2$ ) is 7.0

percentage points more likely to be pro-trade than an individual with the average national income (earnrel =1). In column (2), we run a "horse race" between absolute income and relative income, and show that it is the latter that wins. In fact, the estimated marginal effects of absolute income change sign (and become negative) once earnrel is included. Column (3) shows that self-evaluations of social status (social class) have a similar effect on trade preferences. ${ }^{14}$ Individuals who identify themselves as belonging to one of the upper classes are more likely to be pro-trade. Finally, in column (4) we enter earnrel and social class together and find that they are both individually significant.

The striking regularity that these findings highlight is that trade is generally perceived to be a good thing for individuals at the high end of a country's income distribution, and a bad thing for those at the bottom. These results survive various robustness checks, including embedding the regressions in Table 5 in the economic frameworks we have discussed previously (see also section VIII). We are not aware of any simple economic theory that would explain these findings, and we leave the development of such a theory to further research. We note, however, that our finding is consistent with another empirical regularity of the last couple of decades, namely that expanded trade has generally been associated with a regressive impact on the earnings distribution in both rich and poor countries.

Whatever the underlying story, one interesting implication of the relationship between relative income and pro-trade preferences is worth noting. Consider a political-economy model in which trade policies are determined by the preferences of the median voter (as in Mayer 1984). In countries with greater income inequality the median voter will normally have a lower

\footnotetext{
${ }^{14}$ The correlation between earnrel and self-identified social class is 0.24 .
} 
relative income than in countries with greater equality. Consequently, greater inequality will be associated with higher levels of trade protection across countries.

VII. The role of values, identity, and attachments

We have drawn attention to the importance of non-economic determinants of trade preferences in the introduction. Indeed, some of our most interesting results pertain to the role of values, identity, and attachments in shaping individual preferences on trade policy. These attributes are particularly significant in explaining differences in average trade preferences across countries. We consider three different specifications in Table 6.

First, we look at the impact of community and regional attachments (column (1)). We focus on answers to the following questions: "How close do you feel to
○ (respondent's neighborhood)?" (NEIGHBOR)
○ (respondent's town/city)?" (TOWN)
○ (respondent's county/region)?" (COUNTY)
○ (respondent's country)?" (NATPRID1)
○ (respondent's continent)?" (CONTINENT)

The four possible answers to these questions range from "not close at all" (with a value of 1) to "very close" (a value of 4). The results show a clear pattern. Individuals with strong attachments to their neighborhood, county/region, or nation tend to be less pro-trade. Such attachments tend to be particularly strong in countries like Japan and Spain, and weak in Britain and the U.S (see Table AIII.2 in Appendix III). On the other hand, individuals with strong attachments either to their town/city or their continent--individuals that we may label "cosmopolitans"--are more likely to be pro-trade. 
The second set of issues we look at relates directly to patriotism, nationalism, and chauvinism. In addition to NATPRID1, we focus on the following questions: "How much do you agree or disagree with the following statements?

- I would rather be a citizen of (respondent's country) than of any other country in the world." (NATPRID2)

○ Generally (respondent's country) is a better country than most other countries." (NATPRID3)

O (respondent's country) should follow its own interests, even if this leads to conflicts with other nations." (NATPRID4)

The five possible answers to these questions range from "d isagree strongly" (with a value of 1) to "agree strongly" (a value of 5).

A careful analysis of the impact of patriotism/nationalism on individual preferences needs to distinguish between various degrees of national attachment. On the one hand, national pride entails feelings of patriotism, i.e. genuine attachment to one's own country. On the other, national pride can be associated with feelings of nationalism--or, in its extreme form, chauvinism--i.e. sentiments of superiority of one's own country. Smith and Jarkko (1998) explain the difference between these two concepts:

National pride is the positive affect that the public feels towards their country as a result of their national identity ... National pride is related to feelings of patriotism and nationalism. Patriotism is love of one's country or dedicated allegiance to same, while nationalism is a strong national devotion that places one's own country above all others. National pride co-exists with patriotism and is a prerequisite of nationalism, but nationalism extends beyond national pride and feeling national pride is not equivalent to being nationalistic. Likewise, national pride is not incompatible with cosmopolitanism (literally being a "world citizen"), but nationalism (or at least a strong degree of it) is antithetical to a transnational perspective. [references omitted]

NATPRID1, which inquires about a general sentiment of attachment to the nation, reflects the degree of national pride/patriotism of an individual. NATPRID2 tests the extent of national devotion in a stronger form. We interpret answers to these two questions as reflecting feelings 
both of patriotism and nationalism. ${ }^{15}$ NATPRID3 matches perfectly Smith and Jarkko's (1998) definition of nationalism as a feeling of superiority of one's own country. NATPRID4 applies this nationalistic stand to a practical situation.

In a world where there are gains from trade at the national level, we would expect patriotism to be positively correlated with pro-trade preferences. Regardless of distributional implications, individuals who care about the country as a whole should be in favor of free trade. On the other hand, patriotic individuals might lean towards protection if trade is viewed as a zero-sum game between nations or its social consequences are judged as adverse. The results in column (2) of Table 6 are more in line with the latter interpretation. There is a particularly strong negative relationship between NATPRID2 and pro-trade views. This is significant in explaining the cross-country variation in trade preferences, as NATPRID2 varies greatly among countries. The percentage of respondents that would "rather be citizen of own country than of any other country" varies from 91 percent in the U.S. to only 50 percent in the Netherlands (Table AIII.2).

At the more explicitly nationalistic end of things, the results are as one would have expected. Feelings of superiority of one's own country presumably encourage thoughts of national isolationism, and abstention from political alliances and other international economic relations. Individuals who agree with the statement that their country "should follow its own interests, even if this leads to conflicts with other nations" (NATPRID4) are significantly less likely to be pro-trade. These individuals clearly perceive trade as a zero-sum game. The percentage of respondents who agree with the proposition that their own country's interests

\footnotetext{
${ }^{15}$ At least as defined in Smith and Jarkko's paper (1998), national pride and patriotism are prerequisites of nationalism.
} 
should be followed even at the cost of conflict with others ranges from 73 percent in Bulgaria to 19 percent in Japan (Table AIII.2).

Finally, we turn to pride in specific national achievements. We focus on the following questions: "How proud are you of (respondent's country) in each of the following?

- The way democracy works (DEMOCR)

- Political influence in world (POL_INFL)

- Economic achievements (ECONPRID)

○ Social security system (SSS_PRID)

As might be expected, levels of pride are generally quite low in the former socialist economies: only 9 percent of respondents are proud of the economic achievements of their country in Hungary, compared to 83 percent in West Germany and 82 percent in the U.S (Table AIII.3). As shown in column (3) of Table 6, pride in a country's democracy and economic achievements are positively correlated with pro-trade attitudes. ${ }^{16}$ We take this to indicate that trade is less threatening to individuals who have confidence in their country's political and economic institutions. On the other hand, pride in a country's political influence in the world (where the U.S. tops the list) is negatively associated with pro-trade attributes.

The last column of Table 6 shows a "kitchen sink" regression where we include all the questions we have considered in this section. The results on individual questions are largely unaffected, indicating that the relationships we have analyzed are additive. ${ }^{17}$ The bottom line is that strong neighborhood/community attachments and patriotic/nationalist feelings are powerful predictors of protectionist sentiment. On the other hand, confidence in a county's economic and political institutions (including its social security system) moderates protectionist tendencies.

\footnotetext{
${ }^{16}$ Pride in the social security system is also positively correlated with pro-trade attitudes but not significantly.

${ }^{17}$ The significance of the marginal effects for category $4(\mathrm{dPr}(\mathrm{y}=4))$ are almost unchanged. While a few marginal effects for the top category are not significant anymore, the signs are the same as before.
} 
VIII. How well are we doing?

In Table 7 we present our preferred specification, based on the models we have considered so far. The main constraint in formulating a "summary" model is that missing values for specific questions result in a reduction in the sample size as more explanatory variables are added. The specification in Table 7 represents our compromise. It is meant to capture the essential insights of all the approaches we have used in explaining the formation of trade preferences, with one exception: we have had to exclude regressors that relate to the sectorspecific factors model, because the sample size would become unacceptably low otherwise.

The basic specification is shown with and without country dummies. Note that there are virtually no significant changes in coefficient estimates between the two versions. Note also that the inclusion of country dummies does not greatly improve the overall fit of the regression. (The models in Table 7 are OLS specifications, so that we can interpret $\mathrm{R}^{2}$ 's in the usual fashion.) Even without the country dummies, our preferred specification explains almost a fifth (18 percent) of the variation in trade preferences in our sample. Inclusion of the country dummies raises the adjusted $\mathrm{R}^{2}$ only to 22 percent. In view of the complex nature of the issue at hand and the imperfections of our data, we consider this to be a fair level of success at explaining attitudes towards trade.

At the beginning of the paper, we highlighted the important differences that exist across countries in average pro-trade orientation. How well does our preferred specification do in explaining these cross-country differences? One way of getting at this question is to ask how successful our model is at knocking out the statistical significance of country dummies. The relevant results are shown in Table 8 . In the first column, we present the estimated coefficients 
on the country dummies when no other regressors are included in the regression. ${ }^{18}$ We exclude the dummy for West Germany, so that the coefficient on the constant term represents the average value of TRADE_OP for West Germany while the coefficients on specific country dummies represent the differences in average values between the relevant country and West Germany. ${ }^{19}$ With the exception of Japan, all the country dummies are statistically significant, indicating that there is a statistically significant difference between average trade attitudes in each of these countries and West Germany.

The second column of Table 8 in turn shows the coefficients on these country dummies when the regression includes the regressors in our preferred specification. The key finding is that 9 of the 15 statistically significant dummies in the previous regression are no longer significant at any conventional level. And the magnitudes of the estimated coefficients are closer to zero in all cases (except for Japan). What this indicates is that our specification is fairly successful in explaining average differences in trade preferences across countries.

To see how this works, consider two specific cases, Poland and Sweden. In Poland's case, the average value of TRADE_OP is 0.90 points lower (on a 5-point scale) than in Germany. What accounts for the difference? We can apply the coefficient estimates in column (2) of Table 7 to country-level averages of the regressors to arrive at an approximate decomposition. Our results indicate that some 65 percent of the difference is explained by differences in comparative advantage--i.e., more individuals associate themselves with skillbased gains from trade in Germany than in Poland--more than 20 percent by greater

\footnotetext{
${ }^{18}$ Note that a number of countries had to be dropped because of the unavailability of data on some of the regressors used in the preferred specification.

${ }^{19}$ The country averages implied by these coefficients differ somewhat from the averages reported in Table 1 because the sample in Table 8 is restricted to observations without missing values for the regressors in our preferred specification.
} 
nationalism/patriotism in Poland, and about 6 percent by the greater incidence of perceptions of low social status in Poland. In Sweden's case, the average value of TRADE_OP is 0.33 points smaller than in Germany. Since the patterns of comparative advantage and the skill distribution do not differ greatly in these two countries, the bulk (roughly 60 percent) of the difference between Germany and Sweden is accounted for by greater cosmopolitanism in Germany and greater nationalism/patriotism in Sweden.

\section{$\underline{\text { IX. Concluding remarks }}$}

Attitudes to trade are shaped by a complex set of determinants. As we have documented, preferences over trade are influenced by both economic and non-economic considerations. Values and narrow self-interest both matter. We close by summarizing our main findings.

- Attitudes toward trade are significantly and robustly correlated with an individual's level of human capital, in the manner predicted by the factor endowments model. Highly educated individuals tend to be pro-trade in countries that are well endowed with human capital (the U.S.), but against trade in countries that are poorly endowed with human capital (the Philippines).

- Preferences over trade are also correlated with the trade exposure of the sector in which an individual is employed. Individuals in non-traded sectors tend to be the most protrade, while individuals in sectors with a revealed comparative disadvantage are the most protectionist. Broadly speaking, therefore, the evidence is also consistent with the implications of the sector-specific model, especially when an individual's stated willingness to move is taken into account.

- An individual's relative economic status, measured in terms of either relative income within each country or self-expressed social status, has a very strong positive association 
with pro-trade attitudes. Individuals who rank high in the domestic income distribution or consider themselves to belong to the "upper classes" are significantly more likely to be pro-trade. It is relative income, and not absolute income, that seems to matter.

- Non-economic determinants, in the form of values, identities, and attachments, play a very important role in explaining the variation in preferences over trade. High degrees of neighborhood attachment and nationalism/patriotism are associated with protectionist tendencies, while cosmopolitanism is correlated with pro-trade attitudes. Everything else being the same, individuals who have greater confidence in the functioning of domestic political and economic institutions are less likely to be protectionist.

Our overall empirical framework relies on a combination of the explanatory factors summarized above. We have shown that this framework does a reasonable job of explaining differences across individuals and a fairly good job of explaining differences across countries. We believe we have made progress in answering the question in our title. 


\section{Appendix I: Model Specification: the Ordered Logit Model}

The ordered logit model is built around a latent regression. Given

$$
\mathrm{y}^{*}=\mathrm{X} \beta+\varepsilon,
$$

where $\mathrm{y}^{*}$ is unobserved, we define the probabilities of the five ordered categories as:

$$
\begin{gathered}
\operatorname{Prob}(\mathrm{y}=1 / \mathrm{X})=\operatorname{Prob}\left(\mathrm{y}^{*} \leq \mu_{1}\right)=\mathrm{F}\left(\mu_{1}-\mathrm{X} \beta\right), \\
\operatorname{Prob}(\mathrm{y}=2 / \mathrm{X})=\operatorname{Prob}\left(\mu_{1} \leq \mathrm{y}^{*} \leq \mu_{2}\right)=\mathrm{F}\left(\mu_{2}-\mathrm{X} \beta\right)-\mathrm{F}\left(\mu_{1}-\mathrm{X} \beta\right) \\
\operatorname{Prob}(\mathrm{y}=3 / \mathrm{X})=\operatorname{Prob}\left(\mu_{2} \leq \mathrm{y}^{*} \leq \mu_{3}\right)=\mathrm{F}\left(\mu_{3}-\mathrm{X} \beta\right)-\mathrm{F}\left(\mu_{2}-\mathrm{X} \beta\right) \\
\operatorname{Prob}(\mathrm{y}=4 / \mathrm{X})=\operatorname{Prob}\left(\mu_{3} \leq \mathrm{y}^{*} \leq \mu_{4}\right)=\mathrm{F}\left(\mu_{4}-\mathrm{X} \beta\right)-\mathrm{F}\left(\mu_{3}-\mathrm{X} \beta\right) \\
\operatorname{Prob}(\mathrm{y}=5 / \mathrm{X})=\operatorname{Prob}\left(\mathrm{y}^{*} \geq \mu_{4}\right)=1-\mathrm{F}\left(\mu_{4}-\mathrm{X} \beta\right) .^{20}
\end{gathered}
$$

$\mu_{1}, \mu_{2}, \mu_{3}$ and $\mu_{4} \quad\left(\mu_{1}<\mu_{2}<\mu_{3}<\mu_{4}\right)$ represent the cutoff values of the ordered logit model while $\mathrm{F}(\mathrm{)})$ is the cumulative distribution function of the logistic distribution:

$$
\mathrm{F}(\mathrm{z})=\frac{\mathrm{e}^{\mathrm{z}}}{1+\mathrm{e}^{\mathrm{z}}}=\frac{1}{1+\mathrm{e}^{-\mathrm{z}}}
$$

As in the logit model, the ordered logit model coefficients are not equal to the effect on the probabilities of changes of the independent variables. The marginal effects of changes in the regressors are given by:

$$
\begin{gathered}
\frac{\partial \operatorname{Prob}(\mathrm{y}=1 / \mathrm{X})}{\partial \mathrm{X}}=-\mathrm{f}\left(\mu_{1}-\mathrm{X} \beta\right) \cdot \beta \\
\frac{\partial \operatorname{Prob}(\mathrm{y}=2 / \mathrm{X})}{\partial \mathrm{X}}=-\left[\mathrm{f}\left(\mu_{2}-\mathrm{X} \beta\right)-\mathrm{f}\left(\mu_{1}-\mathrm{X} \beta\right)\right] \cdot \beta \\
\frac{\partial \operatorname{Prob}(\mathrm{y}=3 / \mathrm{X})}{\partial \mathrm{X}}=-\left[\mathrm{f}\left(\mu_{3}-\mathrm{X} \beta\right)-\mathrm{f}\left(\mu_{2}-\mathrm{X} \beta\right)\right] \cdot \beta
\end{gathered}
$$

\footnotetext{
${ }^{20}$ We present the same specification of the model as used by Stata, i.e. a specification without constant in ${ }^{\mathrm{x}}$. Greene's formulation (Greene 2000, p.876) of the ordered logit model includes a constant. Using Stata's estimates, we can calculate the constant in Greene's model as follows: constant=- ${ }^{\mu_{1}}$.
} 


$$
\begin{gathered}
\frac{\partial \operatorname{Prob}(\mathrm{y}=4 / \mathrm{X})}{\partial \mathrm{X}}=-\left[\mathrm{f}\left(\mu_{4}-\mathrm{X} \beta\right)-\mathrm{f}\left(\mu_{3}-\mathrm{X} \beta\right)\right] \cdot \beta \\
\frac{\partial \operatorname{Prob}(\mathrm{y}=5 / \mathrm{X})}{\partial \mathrm{X}}=\mathrm{f}\left(\mu_{4}-\mathrm{X} \beta\right) \cdot \beta
\end{gathered}
$$

Greene observes that, an increase in the regressors keeping $\beta$ and $\mu$ constant, has definitely an unambiguous effect on the probabilities of the first and last categories. However, the impact on the probabilities of the middle categories is ambiguous. Therefore, even a qualitative interpretation of the coefficient estimates, i.e. of the sign of the changes in the probabilities, may be misleading. ${ }^{21}$

In interpreting the ordered logit coefficients, one can use the following fact. A positive coefficient estimate of $\beta_{j}$ means that, given an increase in the regressor $X_{j}$, the probability of category 1 (lowest) decreases and the probability of category 5 (highest) increases, as already pointed out above. Furthermore, a positive coefficient estimate of $\beta_{\mathrm{j}}$ also means that the probability of the lowest two categories ( 1 and 2$)$ decreases while the probability of the highest two categories (4 and 5) increases. ${ }^{22}$

In quantitative terms,

$$
\frac{\partial \operatorname{Pr} o b(y=4 / X)}{\partial X}+\frac{\partial \operatorname{Pr} o b(y=5 / X)}{\partial X}=f\left(\mu_{3}-X \beta\right) \cdot \beta .
$$

Stata numerically calculates the marginal effects of the regressors $\mathrm{X}$ on the probabilities of the five categories (in correspondence of the means of $\mathrm{X}$ ). For each regression, the effect of a change in $\mathrm{X}$ on each of the five probabilities can be calculated.

Concerning the pseudo-R2, we use the formula:

pseudo-R2 = 1 - L1/L0,

where LO and L1 are the constant-only and full model log-likelihoods respectively.

For discrete distributions, the $\log$-likelihood is the $\log$ of a probability, so it is always negative (or zero). Thus, $0>=\mathrm{L} 1>=\mathrm{L} 0$, and so $0<=\mathrm{L} 1 / \mathrm{L} 0<=1$, and so $0<=$ pseudo-R $2<=1$

\footnotetext{
21 " The upshot is that we must be very careful in interpreting the coefficients in this model.... This point seems uniformly to be overlooked in the received literature." (Greene 1993, p. 674)

${ }^{22}$ By probability of the lowest two categories, we mean the probability that the dependent variable is equal to 1 or 2 . Equivalently, by probability of the highest two categories, we mean the probability that the dependent variable is equal to 4 or 5 .
} 
for DISCRETE distributions. For continuous distributions, the log-likelihood is the $\log$ of a density. Since density functions can be greater than 1 (cf. the normal density at 0 ), the $\log$ likelihood can be positive or negative. 


\section{Appendix II: Sectoral classification}

Since in the ISSP-NI survey there is no direct question about industry, we infer sector of employment from data on occupation. We use individual answers to two questions in the data set, one asking for occupation according to an international code (the International Standard Classification of Occupations [ISCO] from 1968 and from 1988) and another one asking for occupation in terms of national codes. Individuals in each country give information about own occupation according to only one of the classifications (either ISCO 1968 or ISCO 1988 or according to a national classification). In particular, individuals' occupations from the following countries are coded according to ISCO 1968: Germany West, Germany East, USA, Austria, Norway, Bulgaria, New Zealand, Spain, Slovak Republic. The occupation codes of this group of countries are recoded all together. Respondents' occupations from the following countries are instead coded according to ISCO 1988: Hungary, Ireland, Czech Republic, Poland, Slovenia, Canada, Russia, Latvia. Again, we recode the occupation codes of this group of countries all together. Finally, respondents' occupations for Great Britain, Sweden, the Philippines, Italy, Netherlands and Japan follow national occupation codes. Data from Great Britain, Sweden and the Philippines are recoded individually. The national occupation codes for Italy, Netherlands and Japan cannot be reclassified since they are not detailed enough.

We reclassify the occupation variables from the ISSP-NI data set in order to match the coding in the World Trade Analyzer (WTA) data set, containing world trade flows from 1980 to 1997. WTA uses a slightly modified version of the Standard International Trade Classification (SITC), Revision 2. However, in the WTA CD-ROM, information is also available in a different format. Data are organized according to the 34 manufacturing industry basis used by the U.S. Bureau of Economic Analysis (BEA). (This coding is quite similar to the U.S. Standard Industrial Classification.) The WTA CD-ROM includes the annual bilateral trade values between all countries in the world in 1980-1997 according to this 34-industry classification. We use the BEA classification to recode the occupation variables in the ISSP-NI data set and construct a new variable indicating the individual sector of employment. The 34 industries (plus one - Non-manufacturing - recoded as 35) are listed below. In order to obtain a more precise match between the ISSP-NI occupation data and the BEA industry codes, we base the recoding on a very detailed description of the correspondence between BEA codes and SITC Revision 2 (four-digit level) codes.

In addition to the 35 BEA industry codes, we create new codes as combinations of the original 35 codes. This is necessary since the occupation codes used in the ISP-NI data set are not always detailed enough to be matched to any single BEA code. The combined codes are listed below. All individuals who cannot be assigned to a single or combined BEA code are matched with either the non-tradable sector or with a missing value. Many occupations naturally fall in the non-tradable sector (for example "jurists," "teachers," "workers in religion").

Individuals with generic occupations such as "company managers," "clerks," "secretaries," and "bookkeepers," are assigned a missing value.

For each of the 35 original BEA industries, we consider sector-specific exports and imports. For each new code, exports (imports) are obtained as sum of exports (imports) of the sectors used in the combination (so, for example, exports of sector 36 are set equal to the sum of 
exports of sectors 17 and 18). We then average both exports and imports over the years 19901995. 
Table AII.1: BEA (Bureau of Economic Analysis) 34 manufacturing industry codes

1. Grain, Mill and Bakery Products

2. Beverages

3. Tobacco Products

4. Other Food and Kindred Products

5. Apparel and Other Textile Products

6. Leather and Leather Products

7. Pulp, Paper and Board Mills

8. Other Paper and Allied Products

9. Printing and Publishing

10. Drugs

11. Soaps, Cleaners, and Toilet Goods

12. Agricultural Chemicals

13. Industrial Chemicals and Synthetics

14. Other Chemicals

15. Rubber Products

16. Miscellaneous Plastic Products

17. Primary Metal Industries, Ferrous

18. Primary Metal Industries, Nonferrous

19. Fabricated Metal Products

20. Farm and Garden Machinery

21. Construction, Mining, etc.

22. Computer and Office Equipment

23. Other Nonelectric Machinery

24. Household Appliances

25. Household Audio and Video, etc.

26. Electronic Components

27. Other Electrical Machinery

28. Motor Vehicles and Equipment

29. Other Transportation Equipment

30. Lumber, Wood, Furniture, etc.

31. Glass Products

32. Stone, Clay, Concrete, Gypsum, etc.

33. Instruments and Apparatus

34. Other Manufacturing

35. Non Manufacturing (.) 
Table AII.2: New codes as combination of original 34 manufacturing industry codes

36. Primary Metal Industries, Ferrous and Nonferrous (17 and 18)

37. Beverages and Other Food and Kindred Products(2 and 4)

38. Electronic Components and Other Electrical Machinery (26 and 27)

39. Drugs and Soaps, Cleaners and Toilet Goods (10 and 11)

40. Industrial Chemicals and Synthetics and Other Chemicals (13 and 14)

41. Rubber Products, Miscellaneous Plastic Products, Primary Metal Industries (Ferrous and Nonferrous) $(15,16,17$ and 18$)$

42. Farm and Garden Machinery and Other Non-electric Machinery (20 and 23)

43. Lumber, Wood, Furniture, etc., Apparel and Other Textile Products and Leather and Leather Products (30,5 and 6)

44. Glass Products and Stone, Clay, Concrete, Gypsum, etc. (31 and 32)

45. Stone, Clay, Concrete, Gypsum, etc. and Non-Manufacturing/Natural Resources (32 and 35)

46. Apparel and Other Textile Products and Leather and Leather Products (5 and 6)

47. Pulp, Paper and Board Mills and Lumber, Wood, Furniture, etc. (7 and 30)

48. Pulp, Paper and Board Mills, Other Paper and Allied Products and Printing and Publishing (7,8 and 9)

49. Primary Metal Industries, Ferrous and Nonferrous and Fabricated Metal Products (17, 18 and 19)

50. Household Audio and Video, etc., Electronic Components and Other Electrical Machinery (25,26 and 27)

51. Pulp, Paper and Board Mills and Other Paper and Allied Products (7 and 8)

52. Grain, Mill and Bakery Products, Beverages and Tobacco Products (1,2 and 3)

53. Primary Metal Industries, Ferrous and Nonferrous, Instruments and Apparatus and Other Manufacturing (17, 18, 33 and 34)

54. Other Food and Kindred Products, Computer and Office Equipment, Household Audio and Video, etc. and Glass Products $(4,22,25,31)$ 


\section{$\underline{\text { References }}$}

Baldwin, Robert E., and Christopher S. Magee, "Is Trade Policy for Sale? Congressional Voting on Recent Trade Bills," NBER Working Paper No. W6376, January 1998.

Balistreri, Edward J., "The Performance of the Heckscher-Ohlin-Vanek Model in Predicting Endogenous Policy Forces at the Individual Level," Canadian Journal of Economics, Vol. 30 No. 1, February 1997, pp. 1-17.

Beaulieu, Eugene "Who supported the Canada-U.S. Free Trade Agreement: Factor or Industry Cleavages in Trade Policy?" University of Calgary, unpublished paper, November 1996.

Beaulieu, Eugene, and Christopher S. Magee, "Campaign Contributions and Trade Policy: New Tests of Stolper-Samuelson," University of Calgary, unpublished paper, May 2001.

Beaulieu, Eugene, Michael Benarroch, and James Gaisford, "Intra-Industry Trade Liberalization: Why Skilled Workers Everywhere Resist Protectionism," University of Calgary, unpublished paper, June 2001.

Feenstra, Robert C., "World Trade Flows, 1980-1997” plus data CD, March 2000.

Greene, William H., Econometric Analysis, London: Prentice-Hall, 2000.

International Social Survey Programme, National Identity, 1995.

Irwin Douglas A., "The Political Economy of Free Trade: Voting in the British General Elections of 1906," Journal of Law and Economics, 37, 1994, pp. 75-108.

Irwin, Douglas A., "Industry or Class Cleavages over Trade Policy? Evidence from the British General Election of 1923," in Robert C. Feenstra, Gene M. Grossman, and Douglas A. Irwin (eds), The Political Economy of Trade Policy: Papers in Honor of Jagdish Bhagwati, Cambridge: The MIT Press, 1996, pp. 53-75.

Magee, "Three Simple Tests of the Stolper-Samuelson Theorem," in Peter Oppenheimer (ed), Issues in International Economics, Stockfield: Oriel Press, 1978.

Mayer, Wolfgang, "Endogeneous Tariff Formation," American Economic Review, 74, 1984, 970985.

Midford, Paul, "International Trade and Domestic Politics: Improving on Rogowski's Model of Political Alignments”, International Organization, 47, 4, Autumn 1993, pp. 535-564.

O’Rourke, Kevin H. and Sinnott, Richard, “The Determinants of Individual Trade Policy Preferences: International Survey Evidence," unpublished paper, April 2001. 
Rodrik, Dani, "Political Economy of Trade Policy," in Gene Grossman and Ken Rogoff (eds), Handbook of International Economics, Volume 3, Netherlands: Elsevier Science Publishers, 1995, pp. 1457-1494.

Rogowski, Ronald "Political Cleavages and Changing Exposure to Trade," American Political Science Review, Vol. 81 No. 4, December 1987, pp. 1121-1137.

Rogowski, Ronald, Commerce and Coalitions, Princeton: Princeton University Press, 1989.

Scheve, Kenneth F. and Slaughter, Matthew J., "What Determines Individual Trade Policy Preferences?” NBER Working Paper \#6531, April 1998.

Scheve, Kenneth F. and Slaughter, Matthew J., Globalization and the Perceptions of American Workers, Institute for International Economics, Washington, DC, 2001.

Smith, Tom W. and Jarkko, Lars, "National Pride: A Cross-national Analysis", National Opinion Research Center/University of Chicago, GSS Cross-national Report No. 19, 1998. 
Table 1: Summary Data on Individual Preferences on Trade Policy

\begin{tabular}{|c|c|c|c|c|c|c|c|c|c|c|c|c|}
\hline \multirow[b]{2}{*}{ Country } & \multicolumn{6}{|c|}{ trade opinion (TRADE_OP) } & \multirow{2}{*}{\multicolumn{2}{|c|}{$\begin{array}{c}\text { average } \\
\text { TRADE_OP }\end{array}$}} & \multirow{2}{*}{\multicolumn{2}{|c|}{ TRADEPRO }} & \multirow{2}{*}{\multicolumn{2}{|c|}{ TRADECON }} \\
\hline & 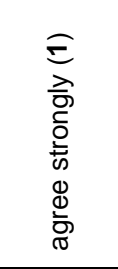 & 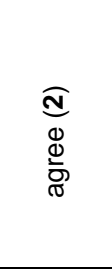 & 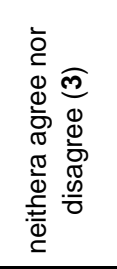 & 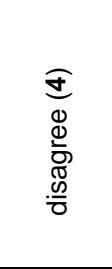 & 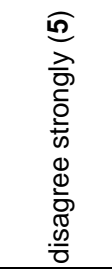 & 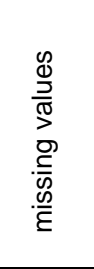 & & & & & & \\
\hline Germany West & 15.13 & 23.71 & 18.49 & 26.83 & 9.52 & 6.32 & 2.91 & 3 & 0.39 & 2 & 0.41 & 20 \\
\hline Germany East & 25.98 & 30.39 & 16.99 & 17.32 & 4.74 & 4.58 & 2.42 & 11 & 0.23 & 13 & 0.59 & 13 \\
\hline Great Britain & 23.16 & 40.17 & 18.53 & 12.38 & 1.42 & 4.35 & 2.25 & 16 & 0.14 & 18 & 0.66 & 10 \\
\hline USA & 21.29 & 43.09 & 16.02 & 10.39 & 2.93 & 6.29 & 2.26 & 16 & 0.14 & 19 & 0.69 & 7 \\
\hline Austria & 37.84 & 31.98 & 10.92 & 12.61 & 3.87 & 2.78 & 2.10 & 20 & 0.17 & 15 & 0.72 & 5 \\
\hline Hungary & 45.40 & 25.80 & 15.80 & 6.90 & 2.60 & 3.5 & 1.92 & 21 & 0.10 & 22 & 0.74 & 4 \\
\hline Italy & 25.78 & 34.73 & 14.53 & 16.09 & 6.58 & 2.29 & 2.42 & 12 & 0.23 & 12 & 0.62 & 12 \\
\hline Ireland & 24.25 & 41.35 & 10.87 & 19.62 & 2.72 & 1.21 & 2.34 & 14 & 0.23 & 14 & 0.66 & 9 \\
\hline Netherlands & 5.12 & 23.93 & 28.24 & 31.93 & 5.51 & 5.27 & 3.09 & 1 & 0.40 & 1 & 0.31 & 23 \\
\hline Norway & 9.10 & 28.49 & 27.37 & 22.79 & 4.91 & 7.33 & 2.85 & 4 & 0.30 & 4 & 0.41 & 21 \\
\hline Sweden & 12.42 & 28.09 & 29.24 & 17.52 & 6.40 & 6.33 & 2.76 & 5 & 0.26 & 10 & 0.43 & 19 \\
\hline Czech Republic & 25.56 & 26.55 & 17.73 & 17.19 & 9.54 & 3.42 & 2.57 & 8 & 0.28 & 6 & 0.54 & 17 \\
\hline Slovenia & 24.03 & 26.83 & 17.95 & 20.46 & 3.96 & 6.76 & 2.50 & 9 & 0.26 & 7 & 0.55 & 15 \\
\hline Poland & 30.04 & 34.86 & 12.70 & 11.76 & 2.63 & 8.01 & 2.15 & 18 & 0.16 & 17 & 0.71 & 6 \\
\hline Bulgaria & 53.57 & 23.80 & 4.98 & 3.26 & 4.52 & 9.86 & 1.68 & 23 & 0.09 & 23 & 0.86 & 1 \\
\hline Russia & 35.58 & 24.48 & 11.74 & 15.02 & 6.81 & 6.37 & 2.28 & 15 & 0.23 & 11 & 0.64 & 11 \\
\hline New Zealand & 17.64 & 34.23 & 19.37 & 19.85 & 4.99 & 3.93 & 2.59 & 7 & 0.26 & 8 & 0.54 & 16 \\
\hline Canada & 14.13 & 31.69 & 21.58 & 21.84 & 6.03 & 4.73 & 2.73 & 6 & 0.29 & 5 & 0.48 & 18 \\
\hline Philippines & 12.75 & 53.75 & 16.33 & 15.17 & 0.83 & 1.17 & 2.37 & 13 & 0.16 & 16 & 0.67 & 8 \\
\hline Japan & 14.09 & 16.80 & 29.54 & 14.97 & 19.03 & 5.57 & 3.09 & 2 & 0.36 & 3 & 0.33 & 22 \\
\hline Spain & 21.21 & 50.12 & 10.97 & 9.25 & 0.98 & 7.45 & 2.12 & 19 & 0.11 & 21 & 0.77 & 2 \\
\hline Latvia & 50.19 & 20.79 & 9.87 & 9.00 & 4.12 & 6.03 & 1.89 & 22 & 0.14 & 20 & 0.76 & 3 \\
\hline Slovak Republic & 26.66 & 28.75 & 15.99 & 16.14 & 8.57 & 3.89 & 2.49 & 10 & 0.26 & 10 & 0.58 & 15 \\
\hline $\begin{array}{l}\text { Mean } \\
\text { Standard Deviation }\end{array}$ & 23.57 & 31.22 & 17.80 & 16.66 & 5.48 & 5.26 & $\begin{array}{l}2.46 \\
1.20\end{array}$ & & $\begin{array}{l}0.23 \\
0.42\end{array}$ & & $\begin{array}{l}0.58 \\
0.49\end{array}$ & \\
\hline
\end{tabular}

The second column of each variable gives the ranking of countries according to that variable.

Bold numbers correspond to highest and lowest values.

TRADEPRO: TRADEPRO $=1$ if TRADE_OP $=4$ or $5 ; 0$ if TRADE_OP $=1,2$ or 3 .

TRADECON: TRADECON=1 if TRADE $O P=1$ or $2 ; 0$ if TRADE $O P=3,4$ or 5

TRADE_OP gives responses to the following question: "How much do you agree or disagree with the following statements: (R's country) should limit the import of foreign products in order to protect its national economy." 
Table 2: Naïve Demographics Model

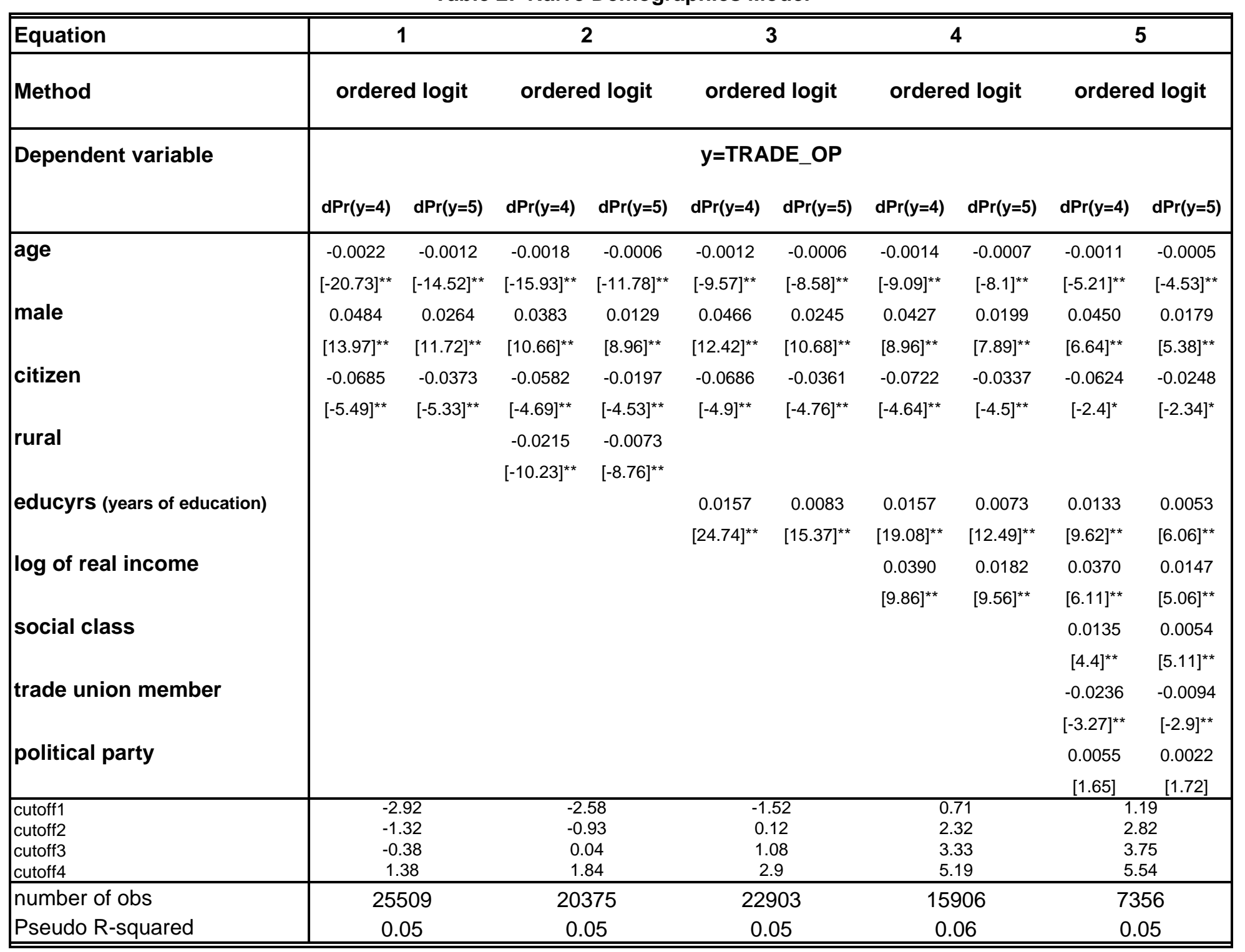

The table contains the estimated marginal effect on the probability of each of the highest two categories, given an increase in the value of the relevant regressor, holding all other regressors at their mean value. Robust $z$ statistics of the marginal effect of each relevant regressor are presented in parentheses.

Each regression includes country dummy variables.

${ }^{*}$ significant at $5 \%$; ** significant at $1 \%$

rural is coded as follows: $1=$ urban, $2=$ suburbs/city-town, $3=$ rural.

social class is coded as follows: $1=$ lower, $2=$ working, $3=$ lower middle, $4=$ middle, $5=$ =upper middle, $6=$ =upper.

political party is coded as follows: $1=$ far left, $2=$ centre left, $3=$ centre, $4=$ right, $5=$ far right. 
Table 3: Factor Endowments Model

\begin{tabular}{|c|c|c|c|c|c|c|c|c|c|c|c|c|c|c|}
\hline Equation & r & 1 & & & 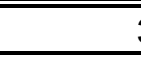 & & & 4 & 5 & & 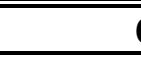 & & & \\
\hline Method & ordere & ed logit & order & d logit & ordere & d logit & order & d logit & ordere & d logit & ordere & d logit & order & d logit \\
\hline Dependent variable & & & & & & & $\mathrm{y}=\mathrm{TR} \boldsymbol{A}$ & DE_OP & & & & & & \\
\hline & $d \operatorname{Pr}(y=4)$ & $\mathrm{dPr}(\mathrm{y}=5)$ & $d \operatorname{Pr}(y=4)$ & $d \operatorname{Pr}(y=5)$ & $\mathrm{dPr}(\mathrm{y}=4)$ & $\mathrm{dPr}(\mathrm{y}=5)$ & $d \operatorname{Pr}(y=4)$ & $\mathrm{dPr}(\mathrm{y}=5)$ & $d \operatorname{Pr}(y=4)$ & $d \operatorname{Pr}(y=5)$ & $d \operatorname{Pr}(y=4)$ & $\mathrm{dPr}(\mathrm{y}=5)$ & $d \operatorname{Pr}(y=4)$ & $\mathrm{dPr}(\mathrm{y}=5)$ \\
\hline age & -0.0011 & -0.0005 & -0.0014 & -0.0005 & -0.0012 & -0.0005 & -0.0010 & -0.0004 & -0.0014 & -0.0006 & -0.0012 & -0.0007 & -0.0012 & -0.0006 \\
\hline & {$[-9.41]^{\star *}$} & {$[-8.22]^{\star *}$} & {$[-8.88]^{\star *}$} & {$[-7.65]^{\star *}$} & {$[-9.31]^{\star *}$} & {$[-8.21]^{\star *}$} & {$[-6.94]^{\star *}$} & {$[-6.45]^{\star *}$} & {$[-8.85]^{\star *}$} & {$[-5.69]^{\star *}$} & {$[-9.74]^{\star *}$} & {$[-8.65]^{\star *}$} & {$[-9.54]^{* *}$} & {$[-8.35]^{\star *}$} \\
\hline male & 0.0435 & 0.0175 & 0.0385 & 0.0151 & 0.0463 & 0.0215 & 0.0564 & 0.0246 & 0.0394 & 0.0179 & 0.0460 & 0.0281 & 0.0468 & 0.0263 \\
\hline & {$[11.68]^{\star *}$} & {$[9.8]^{\star \star}$} & {$[8.04]^{\star *}$} & {$[7]^{\star *}$} & {$[12.01]^{\star \star}$} & {$[9.94]^{\star *}$} & {$[12.82]^{\star *}$} & {$[10.26]^{\star *}$} & {$[8.11]^{\star *}$} & {$[5.35]^{\star \star}$} & {$[12.26]^{\star *}$} & {$[10.53]^{\star \star}$} & {$[12.41]^{\star *}$} & {$[10.41]^{\star *}$} \\
\hline citizen & -0.0655 & -0.0263 & -0.0694 & -0.0273 & -0.0674 & -0.0312 & -0.0710 & -0.0310 & -0.0704 & -0.0319 & -0.0664 & -0.0406 & -0.0681 & -0.0383 \\
\hline & {$[-4.79]^{\star *}$} & {$[-4.61]^{\star *}$} & {$[-4.58]^{\star *}$} & {$[-4.37]^{\star *}$} & {$[-4.87]^{\star *}$} & {$[-4.67]^{\star *}$} & {$[-4]^{\star *}$} & {$[-3.89]^{\star *}$} & {$[-4.55]^{\star *}$} & {$[-3.9]^{* *}$} & {$[-4.81]^{\star *}$} & {$[-4.69]^{\star *}$} & {$[-4.82]^{\star *}$} & {$[-4.69]^{\star *}$} \\
\hline $\begin{array}{l}\text { educyrs } \\
\text { (years of education) }\end{array}$ & -0.0891 & -0.0358 & -0.0737 & -0.0290 & -0.0560 & -0.0260 & -0.1133 & -0.0495 & -0.0821 & -0.0373 & -0.0129 & -0.0079 & 0.0216 & 0.0121 \\
\hline & {$[-10.98]^{\star *}$} & {$[-11.17]^{\star *}$} & {$[-4.98]^{\star *}$} & {$[-5.46]^{\star *}$} & {$[-4.61]^{\star *}$} & {$[-5.06]^{\star *}$} & {$[-4.75]^{\star *}$} & {$[-5.18]^{\star *}$} & {$[-4.98]^{\star *}$} & {$[-4.03]^{\star *}$} & {$[-2.94]^{\star *}$} & {$[-2.72]^{* *}$} & {$[18]^{\star *}$} & {$[14.3]^{* *}$} \\
\hline educyrs*gdp & 0.0109 & 0.0044 & 0.0092 & 0.0036 & 0.0076 & 0.0035 & 0.0135 & 0.0059 & 0.0101 & 0.0046 & & & & \\
\hline & {$[12.93]^{\star *}$} & {$[12.67]^{\star *}$} & {$[6.06]^{\star *}$} & {$[6.69]^{\star *}$} & {$[6.05]^{\star *}$} & {$[6.73]^{\star *}$} & {$[5.58]^{* *}$} & {$[6.12]^{\star \star}$} & {$[5.95]^{\star *}$} & {$[4.51]^{\star *}$} & & & & \\
\hline log of real income & & & 0.0381 & 0.0150 & & & & & 0.1498 & 0.0680 & & & & \\
\hline & & & {$[9.91]^{\star *}$} & {$[9.01]^{* *}$} & & & & & {$[1.77]$} & {$[1.46]$} & & & & \\
\hline income*gdp/cap. & & & & & & & & & -0.0115 & -0.0052 & & & & \\
\hline & & & & & & & & & {$[-1.33]$} & {$[-1.15]$} & & & & \\
\hline educyrs*sk & & & & & & & & & & & & & -0.0016 & -0.0009 \\
\hline & & & & & & & & & & & & & {$[-2.05]^{*}$} & {$[-2.15]^{*}$} \\
\hline educyrs*unsk & & & & & & & & & & & & & 0.0078 & 0.0044 \\
\hline & & & & & & & & & & & & & {$[8.89]^{*}$} & {$[8.22]^{\star *}$} \\
\hline educyrs*educ & & & & & & & & & & & 0.0024 & 0.0015 & & \\
\hline & & & & & & & & & & & {$[6.56]^{\star *}$} & {$[5.44]^{\star *}$} & & \\
\hline $\begin{array}{l}\text { cutoff1 } \\
\text { cutoff2 } \\
\text { cutoff3 } \\
\text { cutoff4 } \\
\end{array}$ & $\begin{array}{c}-1 \\
0 . \\
1 . \\
3 .\end{array}$ & $\begin{array}{l}.19 \\
45 \\
42 \\
26\end{array}$ & & $\begin{array}{l}88 \\
49 \\
.5 \\
38\end{array}$ & $\begin{array}{c}-1 \\
0 . \\
1 . \\
3 .\end{array}$ & & & $\begin{array}{l}13 \\
55 \\
56 \\
44\end{array}$ & $\begin{array}{c}0 . \\
2 . \\
3 . \\
5 .\end{array}$ & & $\begin{array}{r}-1 \\
-0 \\
0 \\
2 \\
2\end{array}$ & $\begin{array}{l}64 \\
01 \\
95 \\
78 \\
\end{array}$ & & $\begin{array}{l}53 \\
11 \\
07 \\
9 \\
\end{array}$ \\
\hline number obs & 22 & 374 & 15 & 393 & 21 & 36 & 17 & 353 & 153 & 393 & 22 & 03 & 22 & 03 \\
\hline Pseudo R-squared & 0. & 05 & & 06 & 0 . & & & 05 & 0. & & 0. & & & \\
\hline
\end{tabular}

The table contains the estimated marginal effect on the probability of each of the highest two categories, given an increase in the value of the relevant regressor, holding all other regressors at their mean value. Robust $z$ statistics of the marginal effect of each relevant regressor are presented in parentheses.

Each regression includes country dummy variables.

In regression (3) the Philippines are dropped. In regression (4) low income countries are not included.

${ }^{*}$ significant at $5 \%$; ** significant at $1 \%$ 
Table 4: Sector Specific Model

\begin{tabular}{|c|c|c|c|c|c|c|c|c|c|c|}
\hline Equation & & & 2 & & 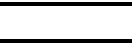 & & $\underline{z}$ & & & \\
\hline Method & order & d logit & ordere & logit & ordere & d logit & ordere & d logit & ordere & d logit \\
\hline Dependent variable & & & & & $y=T R A[$ & E_OP & & & & \\
\hline & $\mathrm{dPr}(\mathrm{y}=4)$ & $\mathrm{dPr}(\mathrm{y}=5)$ & $\mathrm{dPr}(\mathrm{y}=4)$ & $\mathrm{dPr}(\mathrm{y}=5)$ & $\mathrm{dPr}(\mathrm{y}=4)$ & $\mathrm{dPr}(\mathrm{y}=5)$ & $\mathrm{dPr}(\mathrm{y}=4)$ & $\mathrm{dPr}(\mathrm{y}=5)$ & $\mathrm{dPr}(\mathrm{y}=4)$ & $d \operatorname{dPr}(y=5)$ \\
\hline age & $\begin{array}{l}-0.0010 \\
{[-5.81]^{\star \star}}\end{array}$ & $\begin{array}{l}-0.0007 \\
{[-5.5]^{* *}}\end{array}$ & $\begin{array}{l}-0.0010 \\
{[-5.74]^{* *}}\end{array}$ & $\begin{array}{l}-0.0007 \\
{[-5.45]^{\star *}}\end{array}$ & $\begin{array}{l}-0.0010 \\
{[-6.02]^{\star *}}\end{array}$ & $\begin{array}{l}-0.0005 \\
{[-5.42]^{* *}}\end{array}$ & $\begin{array}{l}-0.0010 \\
{[-6.01]^{*}}\end{array}$ & $\begin{array}{l}-0.0005 \\
{[-5.41]^{* *}}\end{array}$ & $\begin{array}{l}-0.0010 \\
{[-5.48]^{* *}}\end{array}$ & $\begin{array}{l}-0.0006 \\
{[-4.81]^{* *}}\end{array}$ \\
\hline male & $\begin{array}{l}0.0454 \\
{[8.79]^{\star *}}\end{array}$ & $\begin{array}{l}0.0307 \\
{[7.74]^{\star *}}\end{array}$ & $\begin{array}{l}0.0430 \\
{[8.34]^{\star *}}\end{array}$ & $\begin{array}{l}0.0293 \\
{[7.49]^{* *}}\end{array}$ & $\begin{array}{l}0.0450 \\
{[8.72]^{\star *}}\end{array}$ & $\begin{array}{l}0.0208 \\
{[7.16]^{\star *}}\end{array}$ & $\begin{array}{l}0.0442 \\
{[8.63]^{\star *}}\end{array}$ & $\begin{array}{l}0.0204 \\
{[7.11]^{\star *}}\end{array}$ & $\begin{array}{l}0.0484 \\
{[8.91]^{\star *}}\end{array}$ & $\begin{array}{l}0.0293 \\
{[7.31]^{\star *}}\end{array}$ \\
\hline citizen & $\begin{array}{l}-0.0427 \\
{[-2.16]^{\star}}\end{array}$ & $\begin{array}{l}-0.0289 \\
{[-2.14]^{*}}\end{array}$ & $\begin{array}{l}-0.0425 \\
{[-2.15]^{*}}\end{array}$ & $\begin{array}{l}-0.0290 \\
{[-2.13]^{*}}\end{array}$ & $\begin{array}{l}-0.0420 \\
{[-2.08]^{*}}\end{array}$ & $\begin{array}{l}-0.0194 \\
{[-2.05]^{*}}\end{array}$ & $\begin{array}{l}-0.0416 \\
{[-2.06]^{*}}\end{array}$ & $\begin{array}{l}-0.0192 \\
{[-2.03]^{*}}\end{array}$ & $\begin{array}{l}-0.0375 \\
{[-1.78]}\end{array}$ & $\begin{array}{l}-0.0227 \\
{[-1.77]}\end{array}$ \\
\hline educyrs (years of education) & $\begin{array}{c}0.0152 \\
{[15.74]^{* *}}\end{array}$ & $\begin{array}{c}0.0102 \\
{[11.16]^{* *}}\end{array}$ & $\begin{array}{c}0.0149 \\
{[15.59]^{* *}}\end{array}$ & $\begin{array}{c}0.0101 \\
{[11.03]^{\star \star}}\end{array}$ & $\begin{array}{l}-0.1060 \\
{[-9.27]^{* *}}\end{array}$ & $\begin{array}{l}-0.0490 \\
{[-9.3]^{\star *}}\end{array}$ & $\begin{array}{l}-0.1043 \\
{[-9.21]^{* *}}\end{array}$ & $\begin{array}{l}-0.0482 \\
{[-9.32]^{\star *}}\end{array}$ & $\begin{array}{c}0.0145 \\
{[15.05]^{\star *}}\end{array}$ & $\begin{array}{l}0.0088 \\
{[9.48]}\end{array}$ \\
\hline educyrsªdp & & & & & $\begin{array}{c}0.0128 \\
{[10.65]^{* *}}\end{array}$ & $\begin{array}{c}0.0059 \\
{[10.22]^{\star *}}\end{array}$ & $\begin{array}{l}0.0126 \\
{[10.6]^{\star *}}\end{array}$ & $\begin{array}{c}0.0058 \\
{[10.25]^{\star *}}\end{array}$ & & \\
\hline imports & & & $\begin{array}{c}-1245.3730 \\
{[-1.9]}\end{array}$ & $\begin{array}{c}-849.5183 \\
{[-1.86]}\end{array}$ & & & $\begin{array}{c}-1075.5040 \\
{[-1.6]}\end{array}$ & $\begin{array}{c}-496.8681 \\
{[-1.57]}\end{array}$ & & \\
\hline exports & & & $\begin{array}{c}-123.0995 \\
{[-0.35]}\end{array}$ & $\begin{array}{c}-83.9711 \\
{[-0.35]}\end{array}$ & & & $\begin{array}{c}-98.7649 \\
{[-0.28]}\end{array}$ & $\begin{array}{c}-45.6281 \\
{[-0.28]}\end{array}$ & & \\
\hline CA sector & $\begin{array}{l}-0.0085 \\
{[-1.07]}\end{array}$ & $\begin{array}{l}-0.0058 \\
{[-1.05]}\end{array}$ & & & $\begin{array}{l}-0.0151 \\
{[-1.86]}\end{array}$ & $\begin{array}{l}-0.0070 \\
{[-1.82]}\end{array}$ & & & $\begin{array}{l}0.0248 \\
{[1.33]}\end{array}$ & $\begin{array}{l}0.0150 \\
{[1.35]}\end{array}$ \\
\hline CD sector & $\begin{array}{l}-0.0256 \\
{[-2.92]^{\star \star}}\end{array}$ & $\begin{array}{l}-0.0173 \\
{[-2.82]^{\star *}}\end{array}$ & & & $\begin{array}{l}-0.0228 \\
{[-2.49]^{\star *}}\end{array}$ & $\begin{array}{l}-0.0106 \\
{[-2.41]^{\star \star}}\end{array}$ & & & $\begin{array}{l}-0.0482 \\
{[-2.23]^{*}}\end{array}$ & $\begin{array}{l}-0.0291 \\
{[-2.13]^{*}}\end{array}$ \\
\hline willingness to move & & & & & & & & & $\begin{array}{l}0.0067 \\
{[2.83]^{\star *}}\end{array}$ & $\begin{array}{l}0.0040 \\
{[3.14]^{\star \star}}\end{array}$ \\
\hline $\mathrm{CA}^{*}$ willingness to move & & & & & & & & & $\begin{array}{l}-0.0103 \\
{[-1.67]}\end{array}$ & $\begin{array}{c}-0.0062 \\
{[-1.68]}\end{array}$ \\
\hline $\mathrm{CD}^{*}$ willingness to move & & & & & & & & & $\begin{array}{c}0.0078 \\
{[1.13]}\end{array}$ & $\begin{array}{l}0.0047 \\
{[1.11]}\end{array}$ \\
\hline $\begin{array}{l}\text { cutoff1 } \\
\text { cutoff2 } \\
\text { cutoff3 } \\
\text { cutoff4 }\end{array}$ & $\begin{aligned}-1.2 \\
0.2 \\
1.1 \\
2.9\end{aligned}$ & & $\begin{array}{l}-1.4 \\
0.1 \\
1.1 \\
2.8\end{array}$ & & & & $\begin{array}{l}-0.9 \\
0.65 \\
1.66 \\
3.4\end{array}$ & & $\begin{array}{r}-1 . \\
0.2 \\
1.2 \\
3.0\end{array}$ & $\begin{array}{l}424 \\
383 \\
746 \\
997\end{array}$ \\
\hline number of obs & & 998 & 11 & & & & 116 & & & \\
\hline Pseudo R-squared & & & 0. & & & & $0 .($ & & & 34 \\
\hline
\end{tabular}

The table contains the estimated marginal effect on the probability of each of the highest two categories, given an increase in the value of the relevant regressor, holding all other regressors at their mean value. Robust $z$ statistics of the marginal effect of each relevant regressor are presented in parentheses.

Each regression includes country dummy variables.

${ }^{*}$ significant at $5 \%$; ** significant at $1 \%$

"imports" refers to the value of imports in the respondent's sector of employment, normalized by GDP

"exports" refers to the value of exports in the respondent's sector of employment, normalized by GDP 
Table 5: Status Model

\begin{tabular}{|c|c|c|c|c|c|c|c|c|}
\hline \multirow{3}{*}{$\begin{array}{l}\text { Equation } \\
\text { Method } \\
\text { Dependent variable }\end{array}$} & \multicolumn{2}{|c|}{1} & \multicolumn{2}{|c|}{2} & \multicolumn{2}{|c|}{3} & \multicolumn{2}{|c|}{4} \\
\hline & \multicolumn{2}{|c|}{ ordered logit } & \multicolumn{2}{|c|}{ ordered logit } & \multicolumn{2}{|c|}{ ordered logit } & \multicolumn{2}{|c|}{ ordered logit } \\
\hline & \multicolumn{8}{|c|}{ y=TRADE_OP } \\
\hline & $\mathrm{dPr}(\mathrm{y}=4)$ & $\mathrm{dPr}(\mathrm{y}=5)$ & $\mathrm{dPr}(\mathrm{y}=4)$ & $\mathrm{dPr}(\mathrm{y}=5)$ & $\mathrm{dPr}(\mathrm{y}=4)$ & $\mathrm{dPr}(\mathrm{y}=5)$ & $\mathrm{dPr}(\mathrm{y}=4)$ & $d \operatorname{Pr}(y=5)$ \\
\hline age & $\begin{array}{l}-0.0014 \\
{[-9.05]^{\star *}}\end{array}$ & $\begin{array}{l}-0.0007 \\
{[-8.11]^{\star *}}\end{array}$ & $\begin{array}{l}-0.0014 \\
{[-8.96]^{\star *}}\end{array}$ & $\begin{array}{l}-0.0007 \\
{[-7.97]^{\star *}}\end{array}$ & $\begin{array}{l}-0.0011 \\
{[-8.97]^{* *}}\end{array}$ & $\begin{array}{l}-0.0004 \\
{[-7.65]^{\star *}}\end{array}$ & $\begin{array}{l}-0.0013 \\
{[-8.45]^{\star *}}\end{array}$ & $\begin{array}{l}-0.0005 \\
{[-7.05]^{\star \star}}\end{array}$ \\
\hline male & $\begin{array}{l}0.0413 \\
{[8.62]^{* *}}\end{array}$ & $\begin{array}{l}0.0212 \\
{[7.86]^{* *}}\end{array}$ & $\begin{array}{l}0.0419 \\
{[8.8]^{\star *}}\end{array}$ & $\begin{array}{l}0.0221 \\
{[7.77]^{\star \star}}\end{array}$ & $\begin{array}{c}0.0430 \\
{[11.33]^{* *}}\end{array}$ & $\begin{array}{l}0.0172 \\
{[9.09]^{\star *}}\end{array}$ & $\begin{array}{l}0.0362 \\
{[7.59]^{\star *}}\end{array}$ & $\begin{array}{l}0.0129 \\
{[6.45]^{\star *}}\end{array}$ \\
\hline citizen & $\begin{array}{l}-0.0735 \\
{[-4.72]^{\star *}}\end{array}$ & $\begin{array}{l}-0.0377 \\
{[-4.58]^{\star *}}\end{array}$ & $\begin{array}{l}-0.0732 \\
{[-4.72]^{\star *}}\end{array}$ & $\begin{array}{l}-0.0386 \\
{[-4.55]^{\star *}}\end{array}$ & $\begin{array}{l}-0.0665 \\
{[-4.84]^{\star *}}\end{array}$ & $\begin{array}{l}-0.0265 \\
{[-4.61]^{\star *}}\end{array}$ & $\begin{array}{l}-0.0688 \\
{[-4.85]^{\star *}}\end{array}$ & $\begin{array}{l}-0.0245 \\
{[-4.56]^{\star *}}\end{array}$ \\
\hline $\begin{array}{l}\text { educyrs } \\
\text { (years of education) }\end{array}$ & $\begin{array}{c}0.0151 \\
{[18.12]^{\star *}}\end{array}$ & $\begin{array}{c}0.0077 \\
{[12.64]^{* *}}\end{array}$ & $\begin{array}{l}0.0151 \\
{[18.18]^{* *}}\end{array}$ & $\begin{array}{l}0.0079 \\
{[12.3]^{\star *}}\end{array}$ & $\begin{array}{l}0.0106 \\
{[13.76]^{\star *}}\end{array}$ & $\begin{array}{l}0.0042 \\
{[9.3]^{\star *}}\end{array}$ & $\begin{array}{l}0.0100 \\
{[9.86]^{\star *}}\end{array}$ & $\begin{array}{l}0.0036 \\
{[7.2]^{\star *}}\end{array}$ \\
\hline log of real income & & & $\begin{array}{l}-0.0090 \\
{[-0.89]}\end{array}$ & $\begin{array}{c}-0.0047 \\
{[-0.86]}\end{array}$ & & & & \\
\hline earnrel (relative income) & $\begin{array}{l}0.0461 \\
{[9.56]^{\star *}}\end{array}$ & $\begin{array}{l}0.0237 \\
{[8.82]^{* \star}}\end{array}$ & $\begin{array}{l}0.0534 \\
{[4.75]^{\star \star}}\end{array}$ & $\begin{array}{l}0.0281 \\
{[4.16]^{* \star}}\end{array}$ & & & $\begin{array}{c}0.0356 \\
{[8]^{\star *}}\end{array}$ & $\begin{array}{l}0.0127 \\
{[7.29]^{\star *}}\end{array}$ \\
\hline social class & & & & & $\begin{array}{c}0.0193 \\
{[11.95]^{\star \star}}\end{array}$ & $\begin{array}{c}0.0077 \\
{[13.61]^{\star *}}\end{array}$ & $\begin{array}{l}0.0151 \\
{[7.83]^{\star \star}}\end{array}$ & $\begin{array}{l}0.0054 \\
{[8.59]^{\star *}}\end{array}$ \\
\hline $\begin{array}{l}\text { cutoff1 } \\
\text { cutoff2 } \\
\text { cutoff3 } \\
\text { cutoff4 }\end{array}$ & & $\begin{array}{l}41 \\
21 \\
21 \\
09 \\
\end{array}$ & $\begin{array}{l}-1 \\
-0 \\
0 . \\
2 \\
\end{array}$ & & & & & $\begin{array}{l}22 \\
36 \\
32 \\
08 \\
\end{array}$ \\
\hline number of obs & & 06 & 15 & & & & & 798 \\
\hline Pseudo R-squared & & & 0. & & & & & 05 \\
\hline
\end{tabular}

The table contains the estimated marginal effect on the probability of each of the highest two categories, given an increase in the value of the relevant regressor, holding all other regressors at their mean value. Robust $z$ statistics of the marginal effect of each relevant regressor are presented in parentheses.

Each regression includes country dummy variables.

* significant at $5 \%$; ${ }^{* *}$ significant at $1 \%$

earnrel is the ratio of individual personal income to the country's (sample) average personal income

social class is coded as follows: $1=$ lower, 2=working, $3=$ lower middle, $4=$ middle, $5=$ =upper middle, $6=$ upper. 
Table 6: Community/National Attachment Model

\begin{tabular}{|c|c|c|c|c|c|c|c|c|}
\hline Equation & & & 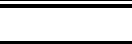 & & & & & \\
\hline Method & order & d logit & order & d logit & order & d logit & order & logit \\
\hline Dependent variable & & & & $y=T R A$ & E_OP & & & \\
\hline & $\mathrm{dPr}(\mathrm{y}=4)$ & $\mathrm{dPr}(\mathrm{y}=5)$ & $\mathrm{dPr}(\mathrm{y}=4)$ & $\mathrm{dPr}(\mathrm{y}=5)$ & $\mathrm{dPr}(\mathrm{y}=4)$ & $\mathrm{dPr}(\mathrm{y}=5)$ & $\mathrm{dPr}(\mathrm{y}=4)$ & $\mathrm{dPr}(\mathrm{y}=5)$ \\
\hline age & $\begin{array}{c}-0.0007 \\
{[-4.79]^{\star *}}\end{array}$ & $\begin{array}{c}-0.0004 \\
{[-4.52]^{\star *}}\end{array}$ & $\begin{array}{l}-0.0004 \\
{[-2.89]^{* *}}\end{array}$ & $\begin{array}{c}-0.0001 \\
{[-2.82]^{\star *}}\end{array}$ & $\begin{array}{c}-0.0010 \\
{[-7.67]^{\star *}}\end{array}$ & $\begin{array}{c}-0.0007 \\
{[-6.81]^{\star *}}\end{array}$ & $\begin{array}{c}-0.0003 \\
{[-1.63]}\end{array}$ & $\begin{array}{c}-0.0001 \\
{[-0.51]}\end{array}$ \\
\hline male & $\begin{array}{c}0.0455 \\
{[10.57]^{* *}}\end{array}$ & $\begin{array}{l}0.0270 \\
{[8.7]^{\star \star}}\end{array}$ & $\begin{array}{l}0.0547 \\
{[13.2]^{\star \star}}\end{array}$ & $\begin{array}{c}0.0197 \\
{[10.67]^{* *}}\end{array}$ & $\begin{array}{c}0.0458 \\
{[10.76]^{\star *}}\end{array}$ & $\begin{array}{l}0.0313 \\
{[8.75]^{\star \star}}\end{array}$ & $\begin{array}{c}0.0565 \\
{[10.99]^{\star *}}\end{array}$ & $\begin{array}{l}0.0178 \\
{[3.46]^{\star *}}\end{array}$ \\
\hline citizen & $\begin{array}{c}-0.0596 \\
{[-3.82]^{\star *}}\end{array}$ & $\begin{array}{c}-0.0353 \\
{[-3.69]^{\star \star}}\end{array}$ & $\begin{array}{l}-0.0347 \\
{[-2.17]^{*}}\end{array}$ & $\begin{array}{l}-0.0125 \\
{[-2.16]^{\star}}\end{array}$ & $\begin{array}{l}-0.0639 \\
{[-4.01]^{\star *}}\end{array}$ & $\begin{array}{c}-0.0436 \\
{[-3.86]^{\star \star}}\end{array}$ & $\begin{array}{c}-0.0344 \\
{[-1.82]}\end{array}$ & $\begin{array}{c}-0.0108 \\
{[-0.57]}\end{array}$ \\
\hline educyrs (years of education) & $\begin{array}{c}0.0143 \\
{[18.99]^{* *}}\end{array}$ & $\begin{array}{c}0.0085 \\
{[11.78]^{\star *}}\end{array}$ & $\begin{array}{c}0.0123 \\
{[17.49]^{*}}\end{array}$ & $\begin{array}{c}0.0044 \\
{[12.18]^{\star *}}\end{array}$ & $\begin{array}{c}0.0149 \\
{[17.27]^{\star \star}}\end{array}$ & $\begin{array}{c}0.0102 \\
{[11.38]^{\star *}}\end{array}$ & $\begin{array}{c}0.0109 \\
{[12.63]^{\star *}}\end{array}$ & $\begin{array}{c}0.0034 \\
{[3.97]^{\star *}}\end{array}$ \\
\hline NEIGHBOR & $\begin{array}{c}-0.0207 \\
{[-6.16]^{\star \star}}\end{array}$ & $\begin{array}{c}-0.0123 \\
{[-5.76]^{\star *}}\end{array}$ & & & & & $\begin{array}{c}-0.0173 \\
{[-4.54]^{\star *}}\end{array}$ & $\begin{array}{c}-0.0055 \\
{[-1.43]}\end{array}$ \\
\hline TOWN & $\begin{array}{c}0.0105 \\
{[2.67]^{\star *}}\end{array}$ & $\begin{array}{c}0.0062 \\
{[2.63]^{\star *}}\end{array}$ & & & & & $\begin{array}{c}0.0116 \\
{[2.59]^{\star \star}}\end{array}$ & $\begin{array}{l}0.0037 \\
{[0.82]}\end{array}$ \\
\hline COUNTY & $\begin{array}{c}-0.0199 \\
{[-5.74]^{\star *}}\end{array}$ & $\begin{array}{c}-0.0118 \\
{[-5.36]^{\star *}}\end{array}$ & & & & & $\begin{array}{c}-0.0164 \\
{[-4.15]^{\star \star}}\end{array}$ & $\begin{array}{c}-0.0052 \\
{[-1.31]}\end{array}$ \\
\hline CONTINENT & $\begin{array}{c}0.0232 \\
{[7.83]^{\star *}}\end{array}$ & $\begin{array}{c}0.0137 \\
{[7.09]^{\star *}}\end{array}$ & & & & & $\begin{array}{l}0.0140 \\
{[4.21]^{\star \star}}\end{array}$ & $\begin{array}{c}0.0044 \\
{[1.32]}\end{array}$ \\
\hline NATPRID1 & $\begin{array}{c}-0.0287 \\
{[-7.81]^{\star \star}}\end{array}$ & $\begin{array}{l}-0.0170 \\
{[-7.24]^{\star *}}\end{array}$ & $\begin{array}{c}-0.0036 \\
{[-1.19]}\end{array}$ & $\begin{array}{l}-0.0013 \\
{[-1.19]}\end{array}$ & & & $\begin{array}{l}-0.0088 \\
{[-2.14]^{*}}\end{array}$ & $\begin{array}{c}-0.0028 \\
{[-0.67]}\end{array}$ \\
\hline NATPRID2 & & & $\begin{array}{c}-0.0442 \\
{[-16.43]^{\star \star}}\end{array}$ & $\begin{array}{c}-0.0160 \\
{[-12.22]^{\star \star}}\end{array}$ & & & $\begin{array}{c}-0.0432 \\
{[-12.53]^{\star *}}\end{array}$ & $\begin{array}{c}-0.0136 \\
{[-3.94]^{* *}}\end{array}$ \\
\hline NATPRID3 & & & $\begin{array}{l}-0.0217 \\
{[-9.15]^{\star *}}\end{array}$ & $\begin{array}{c}-0.0078 \\
{[-8.25]^{\star *}}\end{array}$ & & & $\begin{array}{c}-0.0219 \\
{[-7.91]^{\star \star}}\end{array}$ & $\begin{array}{c}-0.0069 \\
{[-2.49]^{\star *}}\end{array}$ \\
\hline NATPRID4 & & & $\begin{array}{c}-0.0541 \\
{[-23.65]^{\star \star}}\end{array}$ & $\begin{array}{c}-0.0195 \\
{[-15.05]^{\star \star}}\end{array}$ & & & $\begin{array}{c}-0.0533 \\
{[-17.12]^{\star *}}\end{array}$ & $\begin{array}{c}-0.0167 \\
{[-5.38]^{* *}}\end{array}$ \\
\hline DEMOCR (pride in democracy) & & & & & $\begin{array}{l}0.0127 \\
{[3.98]^{\star \star}}\end{array}$ & $\begin{array}{l}0.0086 \\
{[3.33]^{\star *}}\end{array}$ & $\begin{array}{c}0.0195 \\
{[4.44]^{\star *}}\end{array}$ & $\begin{array}{c}0.0061 \\
{[1.4]}\end{array}$ \\
\hline POL_INFL (pride in pol influence) & & & & & $\begin{array}{c}-0.0252 \\
{[-7.76]^{\star \star}}\end{array}$ & $\begin{array}{c}-0.0172 \\
{[-5.67]^{\star *}}\end{array}$ & $\begin{array}{c}-0.0119 \\
{[-2.75]^{\star \star}}\end{array}$ & $\begin{array}{c}-0.0038 \\
{[-0.86]}\end{array}$ \\
\hline ECONPRID (economic pride) & & & & & $\begin{array}{l}0.0069 \\
{[2.05]^{*}}\end{array}$ & $\begin{array}{c}0.0047 \\
{[2.2]^{*}}\end{array}$ & $\begin{array}{c}0.0159 \\
{[4.11]^{\star \star}}\end{array}$ & $\begin{array}{c}0.0050 \\
{[1.29]}\end{array}$ \\
\hline SSS_PRID (pride in social security system) & & & & & $\begin{array}{l}0.0012 \\
{[0.42]} \\
\end{array}$ & $\begin{array}{c}0.0009 \\
{[0.43]}\end{array}$ & $\begin{array}{l}0.0077 \\
{[2.18]^{\star}}\end{array}$ & $\begin{array}{c}0.0024 \\
{[0.69]} \\
\end{array}$ \\
\hline $\begin{array}{l}\text { cutoff1 } \\
\text { cutoff2 } \\
\text { cutoff3 } \\
\text { cutoff4 }\end{array}$ & & & & & & & & \\
\hline number of obs & & & & & & & & \\
\hline Pseudo R-squared & & & & & & & & \\
\hline
\end{tabular}

The table contains the estimated marginal effect on the probability of each of the highest two categories, given an increase in the value of the relevant regressor, holding all other regressors at their mean value. Robust $z$ statistics of the marginal effect of each relevant regressor are presented in parentheses.

Each regression includes country dummy variables.

${ }^{*}$ significant at $5 \%$; ** significant at $1 \%$ 
Table 7: Preferred Specification

\begin{tabular}{|c|c|c|}
\hline$\overline{\text { Equation }}$ & 1 & 2 \\
\hline Method & $\begin{array}{c}\text { OLS } \\
\text { without country } \\
\text { dummies }\end{array}$ & $\begin{array}{c}\text { OLS } \\
\text { with country } \\
\text { dummies }\end{array}$ \\
\hline Dependent variable & \multicolumn{2}{|c|}{ TRADE_OP } \\
\hline $\begin{array}{l}\text { age } \\
\text { male }\end{array}$ & $\begin{array}{r}-0.0021 \\
2.76^{\star \star} \\
0.2421\end{array}$ & $\begin{array}{r}-0.0024 \\
3.07^{* *} \\
0.2131\end{array}$ \\
\hline & $10.14^{* *}$ & $9.08^{* \star}$ \\
\hline educyrs (years of education) & $\begin{array}{r}-0.3029 \\
14.48^{\star \star}\end{array}$ & $\begin{array}{r}-0.3848 \\
5.28^{\star \star}\end{array}$ \\
\hline educyrs* ${ }^{\star} g d p$ & $\begin{array}{r}0.0339 \\
16.22^{\star *}\end{array}$ & $\begin{array}{r}0.0428 \\
5.70^{\star \star}\end{array}$ \\
\hline earnrel & $\begin{array}{r}0.1201 \\
5.90^{* *}\end{array}$ & $\begin{array}{c}0.128 \\
6.39^{\star *}\end{array}$ \\
\hline social class & $\begin{array}{c}0.1212 \\
10.87^{\star *}\end{array}$ & $\begin{array}{r}0.0735 \\
6.31^{\star \star}\end{array}$ \\
\hline NEIGHBOR & $\begin{array}{r}-0.0648 \\
3.71^{\star *}\end{array}$ & $\begin{array}{r}-0.0728 \\
4.13^{\star \star}\end{array}$ \\
\hline TOWN & $\begin{array}{r}0.0635 \\
3.03^{\star *}\end{array}$ & $\begin{array}{r}0.0634 \\
3.04^{* \star}\end{array}$ \\
\hline COUNTY & $\begin{array}{r}-0.0708 \\
3.85^{\star \star}\end{array}$ & $\begin{array}{r}-0.0747 \\
4.10^{\star \star *}\end{array}$ \\
\hline CONTINENT & $\begin{array}{r}0.0108 \\
0.83\end{array}$ & $\begin{array}{r}0.0467 \\
3.33^{\star \star}\end{array}$ \\
\hline NATPRID2 & $\begin{array}{c}-0.152 \\
11.28^{\star *}\end{array}$ & $\begin{array}{r}-0.1394 \\
10.35^{\star \star}\end{array}$ \\
\hline NATPRID3 & $\begin{array}{r}-0.0624 \\
5.21^{\star \star}\end{array}$ & $\begin{array}{r}-0.0866 \\
7.01^{* \star}\end{array}$ \\
\hline $\begin{array}{l}\text { NATPRID4 } \\
\text { constant }\end{array}$ & $\begin{array}{r}-0.1899 \\
17.98^{\star *} \\
3.285 \\
32.36^{\star *}\end{array}$ & $\begin{array}{r}-0.1596 \\
14.76^{\star \star} \\
3.4901 \\
30.49^{\star \star}\end{array}$ \\
\hline number of obs & 9478 & 9478 \\
\hline Adj. R-squared & 0.18 & 0.22 \\
\hline
\end{tabular}

T values in parentheses are robust, i.e. they are calculated using White (1980)-corrected standard errors. ${ }^{*}$ significant at $5 \%$; ** significant at $1 \%$

social class is coded as follows: $1=$ lower, 2=working, 3=lower middle, 4=middle, 5=upper middle, $6=$ =upper. earnrel is the ratio of individual personal income to the country's (sample) average personal income 
Table 8: Power of Main Regressors in Explaining Cross-Country Differences

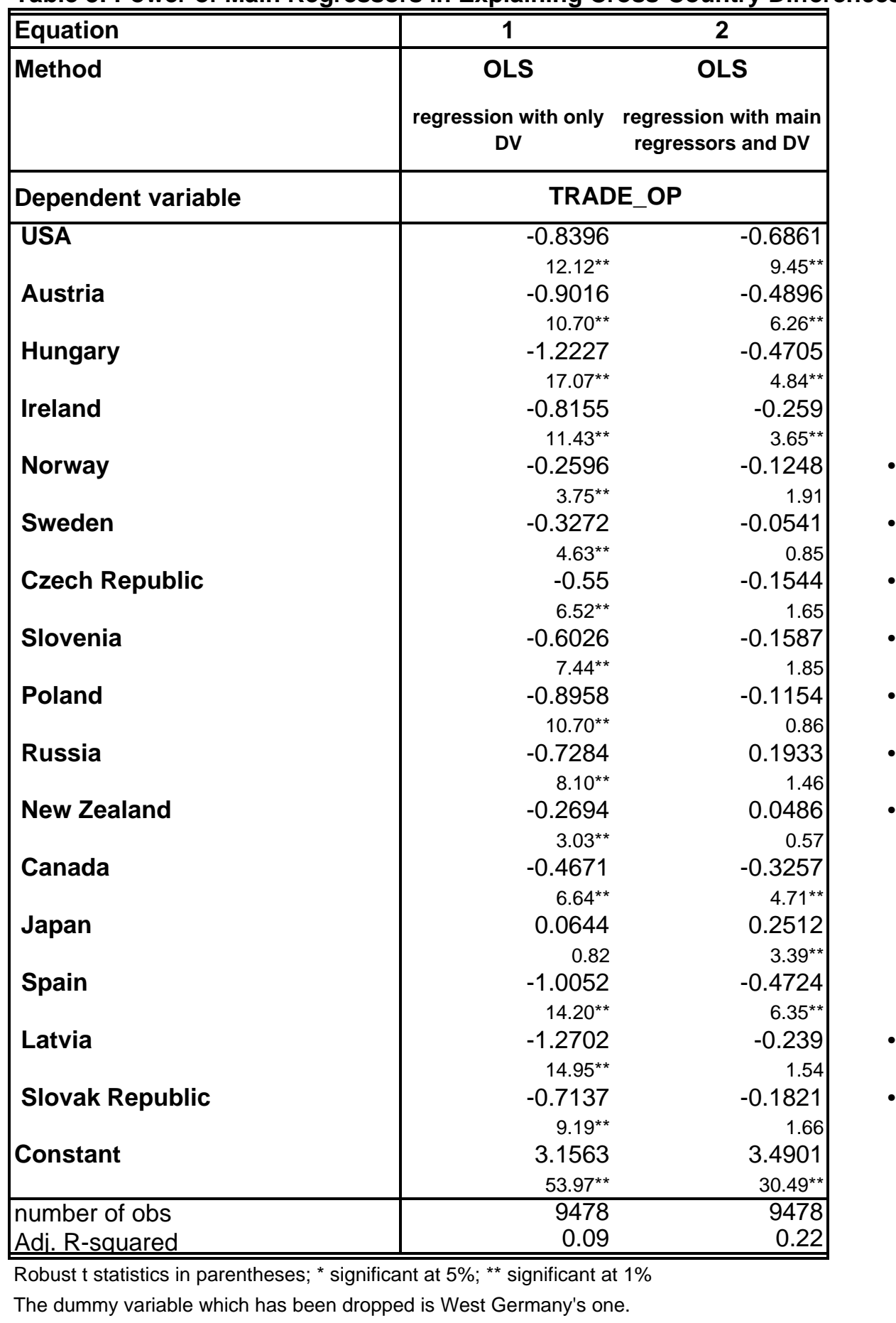




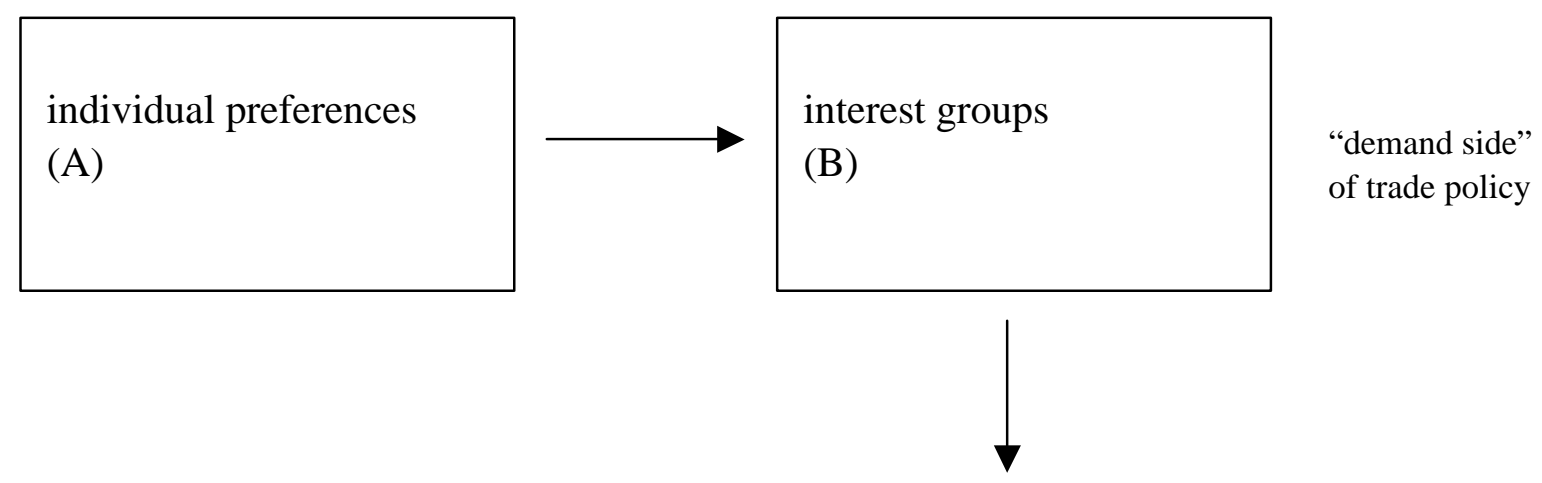

Trade policy outcomes

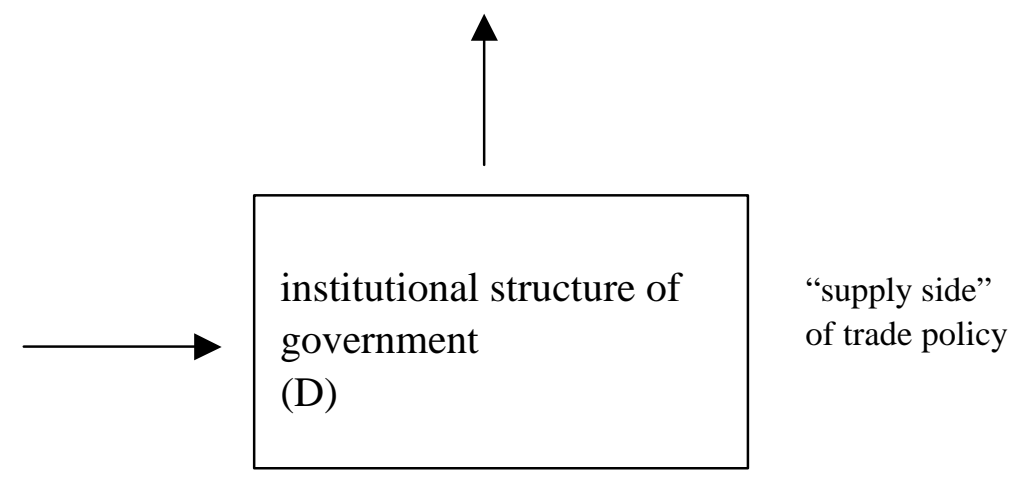

Figure 1: Determination of trade policy 


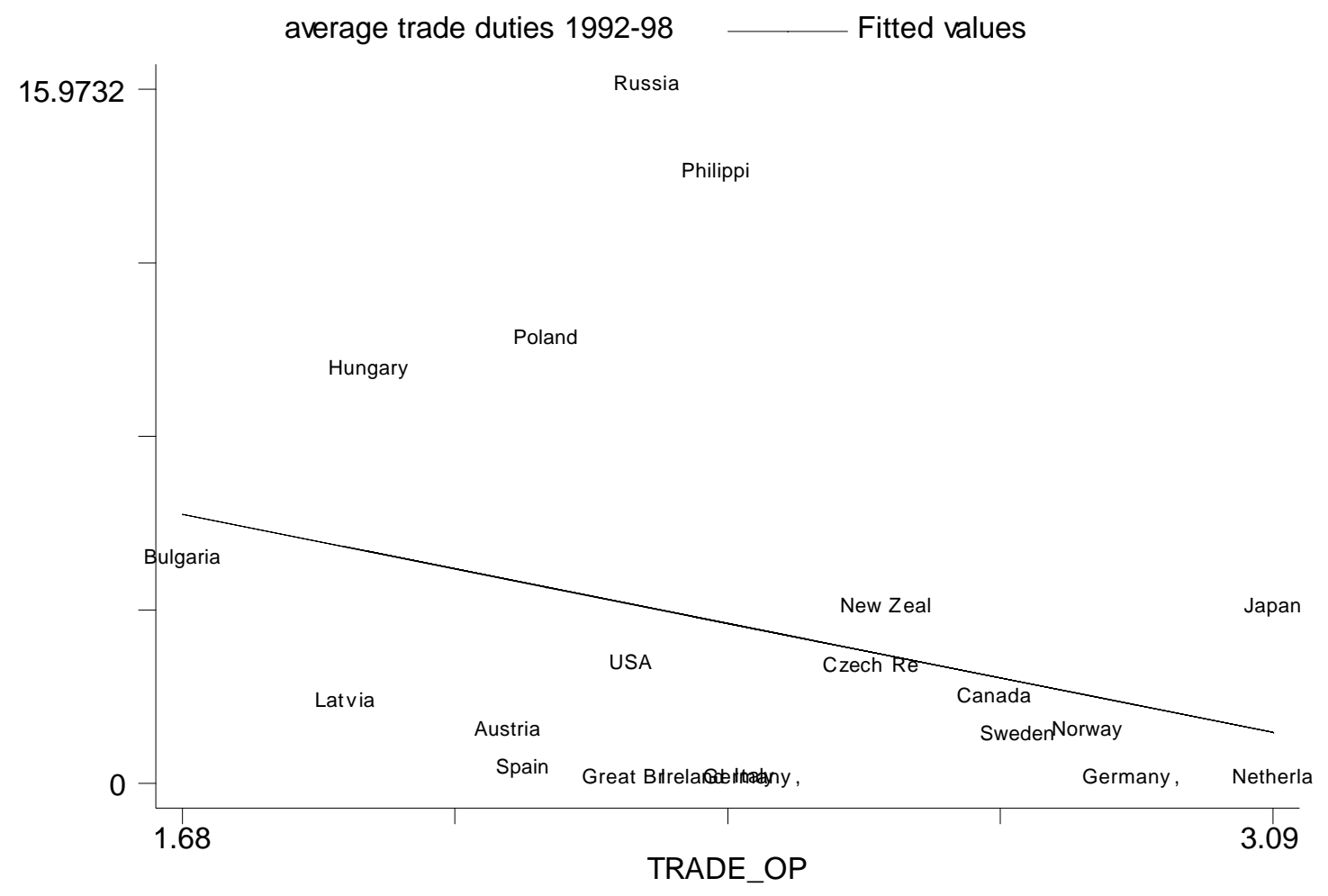

Figure 2: Relationship between TRADE_OP and average trade duties 


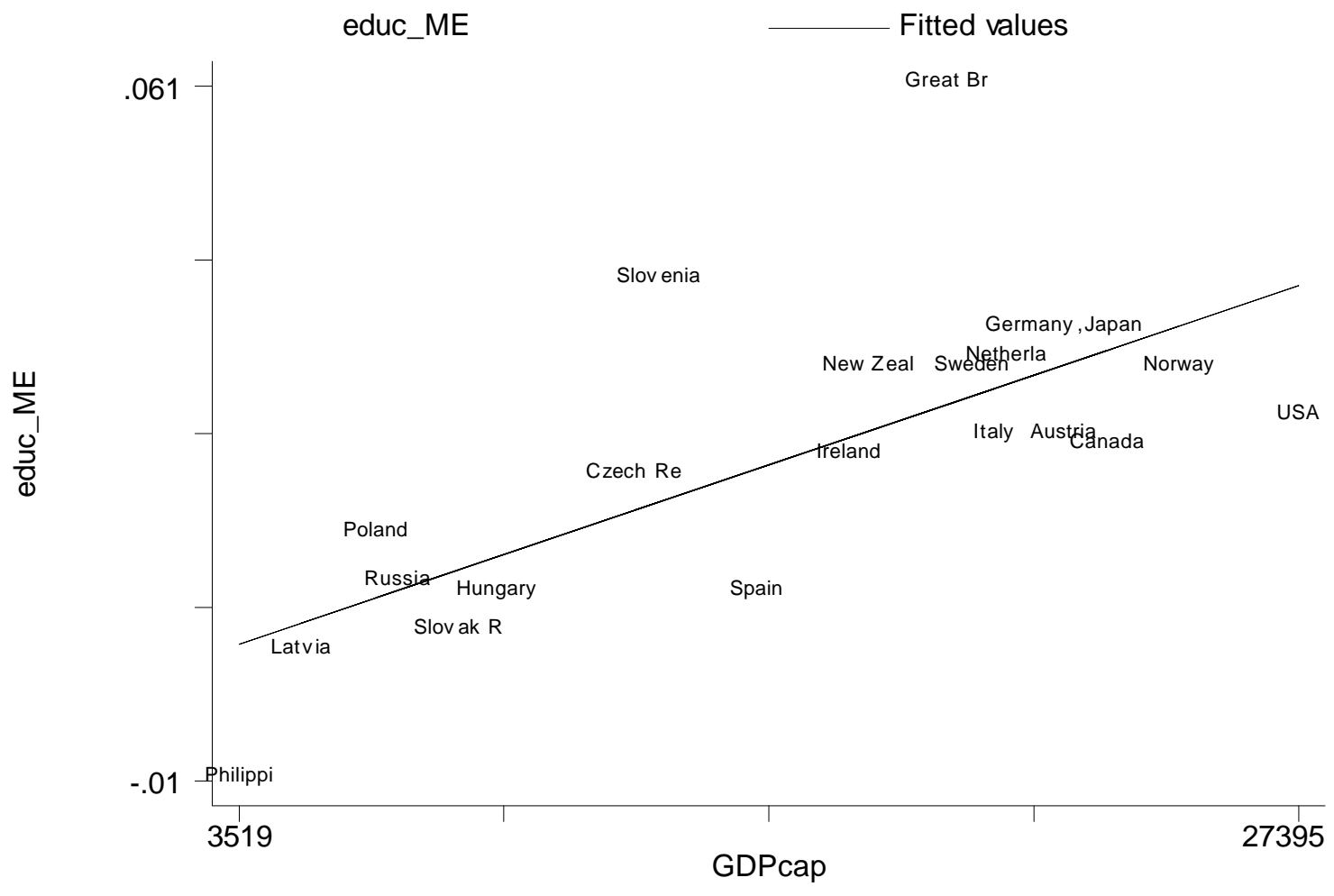

Figure 3: Relationship between per-capita GDP and the estimated marginal effect of education 
Appendix III: Table Alll.1 - Demographic Variables

\begin{tabular}{|c|c|c|c|c|c|c|c|c|c|c|c|c|c|c|c|c|c|}
\hline \multirow[b]{2}{*}{ Country } & \multirow[b]{2}{*}{$\begin{array}{c}\text { number of } \\
\text { observations } \\
\text { in the sample }\end{array}$} & \multirow[b]{2}{*}{ age } & \multirow[b]{2}{*}{$\begin{array}{c}\text { average } \\
\text { years of } \\
\text { education }\end{array}$} & \multirow[b]{2}{*}{ male } & \multirow[b]{2}{*}{ rural } & \multirow[b]{2}{*}{$\begin{array}{l}\text { trade union } \\
\text { membership }\end{array}$} & \multicolumn{6}{|c|}{ subjective social class } & \multicolumn{5}{|c|}{$\begin{array}{l}\text { political party } \\
\text { affiliation }\end{array}$} \\
\hline & & & & & & & 흐 & $\frac{\stackrel{\text { ? }}{\frac{5}{2}}}{3}$ & $\begin{array}{l}\frac{0}{\overline{0}} \\
\frac{0}{E} \\
\bar{\phi} \\
\underline{0}\end{array}$ & $\frac{\frac{0}{D}}{\frac{0}{E}}$ & $\begin{array}{l}\frac{0}{\overline{0}} \\
\frac{0}{\bar{\varepsilon}} \\
\frac{\overline{0}}{0} \\
\frac{0}{3}\end{array}$ & $\begin{array}{l}\bar{\Phi} \\
\frac{\circ}{3}\end{array}$ & 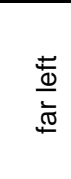 & 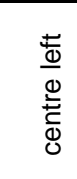 & 竝 & 常 & 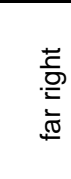 \\
\hline Germany West & 1282 & 46 & 10.93 & 0.54 & - & 0.36 & 2.0 & 0.0 & 16.2 & 56.4 & 16.5 & 1.3 & 0.3 & 49.0 & 5.5 & 36.0 & 2.6 \\
\hline Germany East & 612 & 48 & 10.93 & 0.50 & - & 0.78 & 9.0 & 0.0 & 33.5 & 43.1 & 4.3 & 0.3 & 15.2 & 43.5 & 5.1 & 25.5 & 1.3 \\
\hline Great Britain & 1058 & 47 & 11.34 & 0.40 & - & 0.21 & - & - & - & - & - & - & 0.6 & 42.9 & 14.6 & 26.3 & 0.0 \\
\hline USA & 1367 & 45 & 13.43 & 0.44 & 1.59 & 0.10 & 5.9 & 45.8 & 0.0 & 44.3 & 0.0 & 3.3 & 0.0 & 34.3 & 36.1 & 27.7 & 0.0 \\
\hline Austria & 1007 & 46 & 10.39 & 0.45 & - & 0.46 & 3.7 & 0.0 & 15.5 & 61.8 & 12.5 & 0.8 & 0.0 & 36.2 & 4.5 & 29.9 & 0.0 \\
\hline Hungary & 1000 & 48 & 10.50 & 0.43 & 1.97 & 0.15 & 12.7 & 35.2 & 25.3 & 22.2 & 1.2 & 0.0 & - & - & - & - & - \\
\hline Italy & 1094 & 43 & 11.03 & 0.48 & 1.98 & 0.12 & 1.4 & 0.0 & 11.5 & 71.3 & 13.4 & 2.5 & - & - & - & - & - \\
\hline Ireland & 994 & 46 & 12.26 & 0.49 & 2.02 & 0.26 & 1.6 & 35.3 & 14.3 & 38.7 & 4.3 & 0.5 & 0.0 & 2.4 & 35.4 & 0.9 & 0.0 \\
\hline Netherlands & 2089 & 44 & 12.69 & 0.46 & 1.72 & 0.21 & - & - & - & - & - & - & 6.5 & 18.0 & 26.0 & 15.7 & 2.7 \\
\hline Norway & 1527 & 43 & 12.68 & 0.50 & 2.09 & 0.44 & 0.0 & 30.4 & 6.5 & 39.5 & 8.3 & 0.5 & 0.7 & 38.1 & 18.6 & 19.7 & 0.0 \\
\hline Sweden & 1296 & 45 & 11.43 & 0.49 & 1.23 & 0.71 & 2.4 & 35.2 & 0.0 & 45.1 & 9.2 & 0.7 & 5.8 & 33.3 & 14.0 & 18.0 & 0.0 \\
\hline Czech Republic & 1111 & 43 & 12.91 & 0.51 & 1.65 & 0.21 & 4.1 & 27.3 & 21.2 & 35.0 & 6.4 & 1.3 & 5.1 & 10.8 & 39.3 & 22.6 & 9.0 \\
\hline Slovenia & 1036 & 43 & 10.68 & 0.44 & 2.03 & 0.35 & 3.3 & 34.1 & 0.0 & 47.5 & 6.2 & 0.2 & 0.0 & 4.5 & 9.6 & 17.4 & 1.9 \\
\hline Poland & 1598 & 47 & 10.29 & 0.45 & 1.72 & 0.13 & 7.4 & 41.2 & 0.0 & 39.6 & 4.4 & 2.2 & 0.0 & 24.2 & 9.3 & 4.7 & 0.0 \\
\hline Bulgaria & 1105 & 49 & - & 0.48 & 1.92 & 0.19 & 14.6 & 51.7 & 0.0 & 26.2 & 0.0 & 1.0 & 6.0 & 15.0 & 8.1 & 9.0 & 2.7 \\
\hline Russia & 1585 & 45 & 11.19 & 0.45 & 1.50 & 0.32 & 12.8 & 29.7 & 14.6 & 25.1 & 2.9 & 0.7 & 18.3 & 3.2 & 8.1 & 35.8 & 4.4 \\
\hline New Zealand & 1043 & 46 & 14.33 & 0.47 & 1.50 & 0.15 & 3.4 & 19.0 & 10.6 & 40.9 & 11.8 & 1.0 & 0.0 & 4.2 & 55.2 & 4.9 & 0.0 \\
\hline Canada & 1543 & 42 & 14.78 & 0.49 & 1.16 & 0.20 & 2.6 & 16.4 & 10.2 & 31.8 & 13.1 & 1.5 & 0.9 & 20.0 & 30.1 & 14.6 & 0.0 \\
\hline Philippines & 1200 & 40 & 9.38 & 0.50 & 1.75 & 0.01 & 25.1 & 61.3 & 0.0 & 10.8 & 0.0 & 2.8 & - & - & - & - & - \\
\hline Japan & 1256 & 46 & 11.87 & 0.46 & - & 0.13 & 4.5 & 0.0 & 19.3 & 48.7 & 17.2 & 3.5 & 1.7 & 5.2 & 6.2 & 24.1 & 0.0 \\
\hline Spain & 1221 & 45 & 10.13 & 0.48 & 1.48 & 0.08 & 6.1 & 41.3 & 17.6 & 28.8 & 3.8 & 0.3 & 11.5 & 31.4 & 0.3 & 28.6 & 0.0 \\
\hline Latvia & 1044 & 47 & 11.64 & 0.39 & 0.39 & 0.19 & 11.9 & 43.3 & 21.0 & 0.0 & 9.8 & 0.6 & - & - & - & - & - \\
\hline Slovak Republic & 1388 & 41 & 11.83 & 0.48 & - & 0.32 & 8.7 & 31.0 & 22.0 & 26.6 & 6.6 & 1.7 & 4.9 & 13.2 & 35.8 & 12.7 & 6.4 \\
\hline $\begin{array}{l}\text { Mean } \\
\text { Standard Deviation }\end{array}$ & total $n=28,456$ & $\begin{array}{l}44.77 \\
16.88\end{array}$ & $\begin{array}{c}11.69 \\
3.58\end{array}$ & $\begin{array}{l}0.47 \\
0.50\end{array}$ & $\begin{array}{l}1.69 \\
0.90\end{array}$ & $\begin{array}{l}0.31 \\
0.46\end{array}$ & 7.29 & 30.8 & 12.5 & 40.2 & 7.9 & 1.44 & 6.07 & 33.2 & 29.0 & 29.3 & 2.52 \\
\hline
\end{tabular}

Rural is coded as follows: 1 urban, 2 suburbs/city-town, 3 rural.

Male is coded as follows: 1 male, 0 otherwise (i.e., 0 includes m.v.).

Trade Union Membership is coded as follows: 1 member, 0 otherwise (i.e., 0 includes m.v.)

Both Subjective Social Class and Political Party Affiliation give percentages over the whole national sample (I.e., including m.v.). 
Table Alll.2 - Attachment to Own Neighborhood, Town/City and County/Region and National Pride Variables

\begin{tabular}{|c|c|c|c|c|c|c|c|c|c|c|c|c|c|c|}
\hline \multirow[b]{2}{*}{ Country } & \multicolumn{14}{|c|}{$\%$ in each nation declaring } \\
\hline & \multicolumn{2}{|c|}{$\begin{array}{c}\text { attachment } \\
\text { to own } \\
\text { neighborhood } \\
\text { (NEIGHBOR) }\end{array}$} & \multicolumn{2}{|c|}{$\begin{array}{c}\text { attachment } \\
\text { to own } \\
\text { town/city } \\
\text { (TOWN) }\end{array}$} & \multicolumn{2}{|c|}{$\begin{array}{c}\text { attachment } \\
\text { to own } \\
\text { county/region } \\
\text { (COUNTY) }\end{array}$} & \multicolumn{2}{|c|}{$\begin{array}{c}\text { attachment } \\
\text { to own } \\
\text { country } \\
\text { (NATPRID1) }\end{array}$} & \multicolumn{2}{|c|}{$\begin{array}{c}\text { "rather be } \\
\text { citizen of own } \\
\text { country" } \\
\text { (NATPRID2) }\end{array}$} & \multicolumn{2}{|c|}{$\begin{array}{c}\text { own country } \\
\text { better than } \\
\text { others } \\
\text { (NATPRID3) }\end{array}$} & \multicolumn{2}{|c|}{$\begin{array}{c}\text { in favor of } \\
\text { country's interests } \\
\text { at any cost } \\
\text { (NATPRID4) }\end{array}$} \\
\hline Germany & 0.74 & 12 & 0.72 & 7 & 0.68 & 7 & 0.80 & 4 & 0.69 & 3 & 0.37 & 8 & 0.29 & 5 \\
\hline Great Britain & 0.64 & 3 & 0.56 & 1 & 0.51 & 2 & 0.71 & 2 & 0.73 & 8 & 0.56 & 13 & 0.52 & 16 \\
\hline USA & 0.57 & 2 & 0.60 & 2 & 0.62 & 4 & 0.81 & 5 & 0.91 & 22 & 0.81 & 21 & 0.44 & 13 \\
\hline Austria & 0.83 & 16 & 0.84 & 16 & 0.89 & 20 & 0.91 & 13 & 0.86 & 15 & 0.69 & 17 & 0.62 & 20 \\
\hline Hungary & 0.80 & 14 & 0.84 & 15 & 0.86 & 18 & 0.96 & 22 & 0.87 & 17 & 0.26 & 3 & 0.41 & 10 \\
\hline Italy & 0.68 & 8 & 0.82 & 12 & 0.80 & 16 & 0.87 & 10 & 0.62 & 2 & 0.37 & 7 & 0.30 & 6 \\
\hline Ireland & 0.84 & 17 & 0.83 & 14 & 0.81 & 17 & 0.93 & 15 & 0.86 & 16 & 0.71 & 18 & 0.63 & 21 \\
\hline Netherlands & 0.71 & 10 & 0.71 & 5 & 0.49 & 1 & 0.87 & 9 & 0.50 & 1 & 0.46 & 11 & 0.28 & 4 \\
\hline Norway & 0.51 & 1 & 0.70 & 4 & 0.79 & 15 & 0.94 & 20 & 0.78 & 11 & 0.67 & 16 & 0.38 & 9 \\
\hline Sweden & 0.65 & 4 & 0.66 & 3 & 0.66 & 6 & 0.83 & 7 & 0.70 & 5 & 0.48 & 12 & 0.44 & 12 \\
\hline Czech Republic & 0.81 & 15 & 0.87 & 19 & 0.69 & 9 & 0.92 & 14 & 0.73 & 7 & 0.22 & 1 & 0.31 & 7 \\
\hline Slovenia & 0.77 & 13 & 0.82 & 13 & 0.78 & 14 & 0.93 & 17 & 0.78 & 13 & 0.28 & 4 & 0.28 & 3 \\
\hline Poland & 0.73 & 11 & 0.75 & 9 & 0.64 & 5 & 0.94 & 19 & 0.88 & 19 & 0.39 & 9 & 0.48 & 15 \\
\hline Bulgaria & 0.88 & 21 & 0.89 & 21 & 0.86 & 19 & 0.93 & 16 & 0.88 & 20 & 0.57 & 14 & 0.73 & 22 \\
\hline Russia & 0.67 & 6 & 0.72 & 6 & 0.62 & 3 & 0.82 & 6 & 0.75 & 9 & 0.42 & 10 & 0.61 & 19 \\
\hline New Zealand & 0.65 & 5 & 0.76 & 10 & 0.71 & 11 & 0.94 & 18 & 0.81 & 14 & 0.78 & 20 & 0.52 & 17 \\
\hline Canada & 0.69 & 9 & 0.76 & 11 & 0.74 & 13 & 0.74 & 3 & 0.78 & 12 & 0.77 & 19 & 0.43 & 11 \\
\hline Philippines & 0.86 & 19 & 0.73 & 8 & 0.68 & 8 & 0.68 & 1 & 0.88 & 18 & 0.59 & 15 & 0.37 & 8 \\
\hline Japan & 0.91 & 22 & 0.88 & 20 & 0.89 & 21 & 0.95 & 21 & 0.89 & 21 & 0.84 & 22 & 0.19 & 1 \\
\hline Spain & 0.88 & 20 & 0.92 & 22 & 0.90 & 22 & 0.89 & 12 & 0.73 & 6 & 0.36 & 6 & 0.61 & 18 \\
\hline Latvia & 0.68 & 7 & 0.85 & 18 & 0.69 & 10 & 0.86 & 8 & 0.76 & 10 & 0.32 & 5 & 0.44 & 14 \\
\hline Slovak Republic & 0.84 & 18 & 0.85 & 17 & 0.73 & 12 & 0.89 & 11 & 0.69 & 4 & 0.23 & 2 & 0.23 & 2 \\
\hline Mean & 0.74 & & 0.78 & & 0.73 & & 0.87 & & 0.78 & & 0.51 & & 0.43 & \\
\hline Standard Deviation & 0.11 & & 0.10 & & 0.12 & & 0.08 & & 0.10 & & 0.20 & & 0.15 & \\
\hline
\end{tabular}

The second column of each variable gives the ranking of countries according to that variable.

Bold numbers correspond to highest and lowest values. 
Table Alll.3 - Pride in Specific Achievements

\begin{tabular}{|l|cc|cc|cc|cc|}
\hline \hline \multirow{2}{*}{ Country } & \multicolumn{7}{|c|}{ \% in each nation declaring } \\
\cline { 2 - 8 } & $\begin{array}{c}\text { proud of } \\
\text { national } \\
\text { democracy }\end{array}$ & $\begin{array}{c}\text { proud of political } \\
\text { influence } \\
\text { in the world }\end{array}$ & $\begin{array}{c}\text { proud } \\
\text { of economic } \\
\text { achievements }\end{array}$ & $\begin{array}{c}\text { proud of } \\
\text { social security } \\
\text { system }\end{array}$ \\
\hline Germany & 0.57 & 12 & 0.61 & 16 & $\mathbf{0 . 8 3}$ & 22 & 0.62 & 17 \\
Great Britain & 0.68 & 15 & 0.55 & 15 & 0.44 & 12 & 0.48 & 12 \\
USA & 0.83 & 20 & $\mathbf{0 . 8 0}$ & 22 & 0.82 & 19 & 0.50 & 13 \\
Austria & 0.71 & 16 & 0.63 & 17 & 0.82 & 21 & $\mathbf{0 . 8 4}$ & 22 \\
Hungary & $\mathbf{0 . 2 0}$ & 1 & $\mathbf{0 . 1 8}$ & 1 & $\mathbf{0 . 0 9}$ & 1 & $\mathbf{0 . 0 7}$ & 1 \\
Italy & 0.26 & 6 & 0.23 & 3 & 0.40 & 9 & 0.28 & 8 \\
Ireland & 0.75 & 18 & 0.79 & 21 & 0.82 & 20 & 0.65 & 19 \\
Netherlands & 0.84 & 21 & 0.49 & 13 & 0.78 & 16 & 0.83 & 21 \\
Norway & 0.80 & 19 & 0.78 & 19 & 0.80 & 18 & 0.62 & 16 \\
Sweden & 0.64 & 13 & 0.41 & 11 & 0.17 & 3 & 0.65 & 18 \\
Czech Republic & 0.35 & 8 & 0.51 & 14 & 0.42 & 11 & 0.19 & 6 \\
Slovenia & 0.21 & 3 & 0.29 & 4 & 0.34 & 8 & 0.30 & 9 \\
Poland & 0.24 & 5 & 0.36 & 6 & 0.28 & 6 & 0.17 & 4 \\
Bulgaria & 0.31 & 7 & 0.36 & 7 & 0.26 & 5 & 0.18 & 5 \\
Russia & $\mathbf{0 . 2 0}$ & 1 & 0.32 & 5 & 0.16 & 2 & 0.08 & 2 \\
New Zealand & 0.73 & 17 & 0.71 & 18 & 0.72 & 15 & 0.39 & 10 \\
Canada & $\mathbf{0 . 8 4}$ & 22 & 0.79 & 20 & 0.62 & 14 & 0.81 & 20 \\
Philippines & 0.53 & 10 & 0.39 & 9 & 0.50 & 13 & 0.52 & 14 \\
Japan & 0.66 & 14 & 0.45 & 12 & 0.80 & 17 & 0.47 & 11 \\
Spain & 0.54 & 11 & 0.40 & 10 & 0.41 & 10 & 0.53 & 15 \\
Latvia & 0.40 & 9 & 0.38 & 8 & 0.21 & 4 & 0.12 & 3 \\
Slovak Republic & 0.22 & 4 & 0.19 & 2 & 0.31 & 7 & 0.22 & 7 \\
\hline Mean & 0.52 & & 0.48 & & 0.50 & & 0.43 & \\
Standard Deviation & 0.24 & & 0.20 & & 0.26 & & 0.25 & \\
\hline
\end{tabular}

The second column of each variable gives the ranking of countries according to that variable.

Bold numbers correspond to highest and lowest values. 